\title{
Review Article \\ Roles of Dietary Bioactive Peptides in Redox Balance and Metabolic Disorders
}

\author{
Qinqin Qiao $\mathbb{D}^{1},{ }^{1}$ Liang Chen, ${ }^{2}$ Xiang Li $\mathbb{D},{ }^{3}$ Xiangyang $\mathrm{Lu}^{2}$ and Qingbiao Xu $\mathbb{D}^{3}$ \\ ${ }^{1}$ College of Information Engineering, Fuyang Normal University, Fuyang 236041, China \\ ${ }^{2}$ College of Bioscience and Biotechnology, Hunan Agricultural University, Changsha 410128, China \\ ${ }^{3}$ College of Animal Sciences and Technology, Huazhong Agricultural University, Wuhan 430070, China
}

Correspondence should be addressed to Qingbiao Xu; qbxu@mail.hzau.edu.cn

Received 21 January 2021; Revised 30 April 2021; Accepted 21 May 2021; Published 15 June 2021

Academic Editor: Wuquan Deng

Copyright (c) 2021 Qinqin Qiao et al. This is an open access article distributed under the Creative Commons Attribution License, which permits unrestricted use, distribution, and reproduction in any medium, provided the original work is properly cited.

Bioactive peptides (BPs) are fragments of 2-15 amino acid residues with biological properties. Dietary BPs derived from milk, egg, fish, soybean, corn, rice, quinoa, wheat, oat, potato, common bean, spirulina, and mussel are reported to possess beneficial effects on redox balance and metabolic disorders (obesity, diabetes, hypertension, and inflammatory bowel diseases (IBD)). Peptide length, sequence, and composition significantly affected the bioactive properties of dietary BPs. Numerous studies have demonstrated that various dietary protein-derived BPs exhibited biological activities through the modulation of various molecular mechanisms and signaling pathways, including Kelch-like ECH-associated protein 1/nuclear factor erythroid 2-related factor 2/antioxidant response element in oxidative stress; peroxisome proliferator-activated- $\gamma$, CCAAT/enhancer-binding protein- $\alpha$, and sterol regulatory element binding protein 1 in obesity; insulin receptor substrate-1/phosphatidylinositol 3-kinase/protein kinase B and AMP-activated protein kinase in diabetes; angiotensin-converting enzyme inhibition in hypertension; and mitogen-activated protein kinase and nuclear factor-kappa B in IBD. This review focuses on the action of molecular mechanisms of dietary BPs and provides novel insights in the maintenance of redox balance and metabolic diseases of human.

\section{Introduction}

Dietary food proteins contain short sequences of amino acids (AAs) that possess various biological activities. The short chains of AAs with biological properties are known as bioactive peptides (BPs). BPs usually contain 2-15 AA residues. The BP sequences present in the food proteins are generally hidden in the inner core of the parent proteins [1]. However, bioactive peptides can be released from food proteins with the help of several techniques including proteolysis, microbial fermentation, and gastrointestinal (GI) digestion [2-4]. Among these methods, in vitro enzymatic hydrolysis using commercial proteolytic enzymes is the widely employed method in recent times. The proteases cleave the specific sites on the dietary proteins and release the short chains of BPs [5]. Enzymatic hydrolysis of dietary proteins enhances the nutritional value, bioactivity, and functionality and reduces the allergenicity [6]. Several commercial proteases, namely, thermolysin, bromelain, trypsin, alcalase, papain, pepsin, neutrase, pancreatin, corolase, protamex, and pronase, have been employed to generate biologically active peptides from various dietary proteins. Among the above-mentioned proteases, alcalase, trypsin, pepsin, and pancreatin are the most widely used proteases for the preparation of peptides, with various health benefitting properties, from numerous food sources [7-10]. These enzymes are routinely used due to their broad specificity to produce smaller peptides with various bioactivities and easily availability.

Dietary BPs have been shown to positively affect the various systems of the human body including the immune, cardiovascular, GI, and nervous systems [11]. The BPs must cross the GI barrier and reach the target tissue or organ in order to exhibit health benefits. Dietary peptides exert bioactivities through the modulation (either enhance or decrease) of various molecular mechanisms and pathways. Bioactive properties of dietary peptides are affected by the peptide sequence, length, hydrophobicity, and composition [12-14]. Dietary peptides are easily absorbable across the intestinal 
border via peptide transport 1 (PepT1) and possess excellent functional properties (solubility, foaming, and emulsification properties) [15-18]. Additionally, dietary BPs are generally safer than synthetic drugs. Hence, BPs obtained from dietary sources could be used as health foods/nutraceuticals in the management/prevention of various diseases. Numerous BPs derived from whey, casein, milk, soybean, shark, bonita, pacific whiting, porcine, and bovine have been on the market in various countries for human use as functional foods/health foods/nutraceuticals [19].

Redox homeostasis (balance) is an important cellular process that plays a vital role in the maintenance of a normal physiological steady state [20]. Disturbance of balance between oxidants and antioxidants results in the oxidative stress. Recently, many BPs prepared from various food sources such as walnut, egg, fish, quinoa, soybean, millets, corn, wheat, rice, potato, milk, and spirulina have shown to possess beneficial effects in the maintenance of redox homeostasis and prevention/management of metabolic diseases [21-26]. However, reviews describing the role of dietary BPs in the modulation of molecular mechanisms of redox balance and metabolic diseases are scanty in the literature. Hence, the current review focuses on the recent literature related to the effects of dietary BPs on various molecular mechanisms and signaling pathways involved in the redox homeostasis and metabolic diseases (obesity, diabetes, hypertension, and inflammation), as shown in Figure 1.

\section{Roles of Dietary Bioactive Peptides in Maintaining Redox Balance}

Redox reaction is a chemical reaction that involves the transfer of electrons from the reducing agent to the oxidizing agent [27]. Redox homeostasis (balance) plays a significant role in the maintenance of ordinary physiological functions of the human body. Redox balance is considerably affected by reactive oxygen species (ROS) that are generated during aerobic cellular metabolism [28]. Reactive oxygen species are unstable and highly reactive in the redox reactions due to the presence of unpaired electrons in the outer shells. Under normal physiological conditions, redox balance is maintained through careful regulation of ROS generation and elimination from the body [29]. However, excess production of ROS during oxidative stress conditions could alter the intracellular redox balance and promote the development of numerous diseases such as cancer, diabetes, atherosclerosis, cardiovascular, and neurodegenerative diseases. The body's natural antioxidant defense system, namely, superoxide dismutase (SOD), glutathione peroxidase (GPx), and catalase (CAT), plays a vital role in the maintenance of balance between ROS formation and elimination [30].

Several studies have demonstrated that a number of peptides identified from various dietary sources have shown the ability to suppress oxidative stress and maintain the redox balance through multiple molecular mechanisms such as scavenging free radicals; chelating transition metals; enhancing the production of endogenous antioxidant enzymes SOD, CAT, and GPx; and stimulating the nuclear factor erythroid 2-related factor 2 (Nrf2) antioxidant defense mechanism
$[12,15,17,26,31-34]$. The antioxidant mechanisms showed by the dietary peptides mainly depend on the peptide sequence, length, composition, and hydrophobicity [12, 34, 35]. The food-derived antioxidant peptides usually contain 3-15 AA residues [12, 32]. Table 1 shows the AA sequences and molecular mechanisms of antioxidant peptides produced from various dietary proteins.

The Kelch-like ECH-associated protein 1- (Keap1-) Nrf2antioxidant response element (ARE) is the main antioxidant signaling pathway that prevents oxidative stress and helps maintain the optimum redox steady state in the body [36]. The Nrf2 is a vital leucine zipper transcription factor, which controls the expression of several antioxidant proteins in response to ROS stress. Keap1 is a suppressor protein for Nrf2, and under a normal ROS steady state, Keap1 binds with Nrf2 and helps proteasome to degrade the Keap1-Nrf2 complex. However, Nrf2 separates from Keap1 during oxidative stress and migrates to the nucleus where it attaches to ARE and thereby promotes the expression of several antioxidant enzymes/proteins [32, 37, 38]. Endogenous antioxidant enzymes such as SOD, GPx, and CAT scavenge different kinds of ROS and thereby protect the cells from oxidative stress-induced damage. SOD catalyses the transformation of superoxide anion to $\mathrm{O}_{2}$ and $\mathrm{H}_{2} \mathrm{O}_{2}$. CAT converts $\mathrm{H}_{2} \mathrm{O}_{2}$ to $\mathrm{H}_{2} \mathrm{O}$ and $\mathrm{O}_{2}$. GPx helps in the reduction of $\mathrm{H}_{2} \mathrm{O}_{2}$ to $\mathrm{H}_{2} \mathrm{O}$ and $\mathrm{O}_{2}$ [39]. Hence, it is important to stimulate the Nrf2 antioxidant signaling pathway to suppress/prevent the oxidative stress in the body.

Recently, numerous novel antioxidant peptides that stimulate the Keap1-Nrf2-ARE antioxidant signaling pathway and antioxidant enzymes have been isolated from different dietary sources such as casein [40], milk protein concentrate [41], corn gluten [31], soybean [42], walnut [43], potato, Moringa oleifera seeds [25], watermelon seeds [39], Crassostrea rivularis [44], krill [38], turtle [45], Mytilus coruscus [46], Channa argus [3], and silver carp muscle [12]. Snakehead (Channa argus) soup was hydrolyzed using pepsin and pancreatin and identified four antioxidant peptides, IVLPDEGK, PGMLGGSPPGLLGGSPP, SDGSNIHFPN, and SVSIRADGGEGEVTVFT [3]. The authors performed molecular docking studies for the peptides and indicated that peptides could bind to the active site of Keapl and thereby activate the cellular antioxidant Keap1-Nrf2 signaling pathway. A peptide RDPEER isolated from alcalase hydrolysate of watermelon seed reduced the oxidative stress by reducing ROS and increasing the antioxidant enzymes, SOD, CAT, and GSH-Px, in HepG2 cells [39]. Four casein-derived peptides, ARHPHPHLSFM, AVPYPQR, NPYVPR, and KVLPVPEK, were shown to decrease the oxidative stress in Caco-2 cells by enhancing antioxidant enzymes, namely, SOD1, Trx1, GR, TrxR1, and NQO1, through the activation of the Keap1-Nrf2 signaling mechanism. It was found that the peptides bound to the Nrf2 and prevented the binding between Keap1 and Nrf2 and thereby stimulated the increased expression of antioxidant enzymes [32]. In a study, a peptide, AMVDAIAR, isolated from pepsin hydrolysate of krill enhanced antioxidant enzymes SOD, CAT, and GPX and thereby suppressed the oxidative stress in $\mathrm{H}_{2} \mathrm{O}_{2}$-induced hepatocytes through increasing the expression of Nrf2 [38]. 


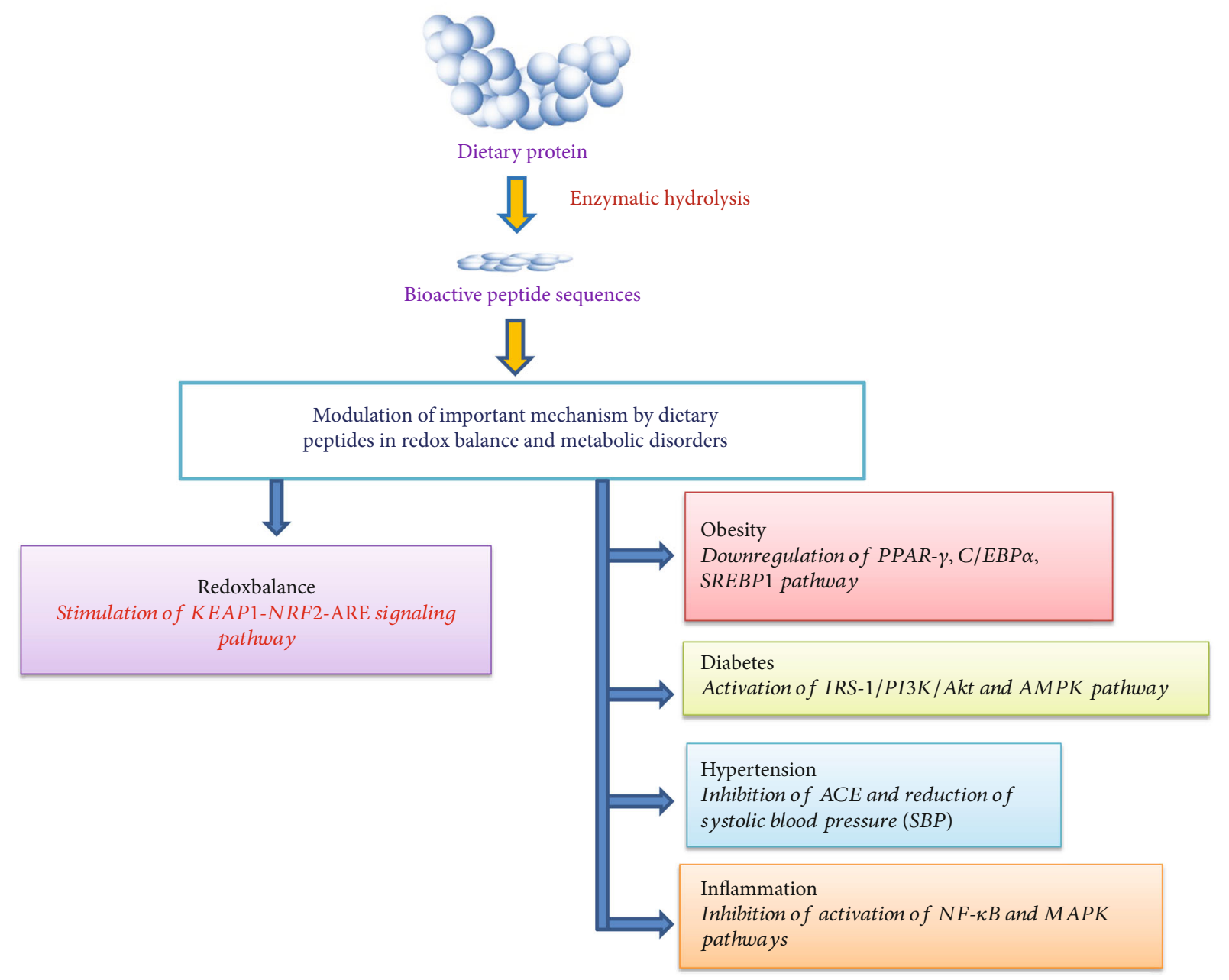

FIGURE 1: Effects of dietary bioactive peptides on molecular mechanisms involved in redox balance and metabolic disorders. ACE: angiotensin-converting enzyme; Akt: protein kinase B; AMPK: AMP-activated protein kinase; ARE: antioxidant response element; C/EBP: CCAAT-enhancer-binding proteins; IRS-1: insulin receptor substrate; PPAR: peroxisome proliferator-activated receptor; Keap1: Kelch-like $\mathrm{ECH}$-associated protein 1; MAPK: mitogen-activated protein kinase; NF- $\kappa \mathrm{B}$ : nuclear factor- $\kappa \mathrm{B}$; Nrf2: nuclear factor erythroid 2-related factor 2; PI3K: phosphatidylinositol 3-kinase; SREBP1: sterol regulatory element-binding protein 1.

Peptide EDYGA derived from soft-shelled turtle enhanced the Nrf2 level through the binding of the glutamate residue of the peptide to Arg 415 of the Kelch receptor pocket [45]. Dipeptide IF identified from potato exhibited antioxidant effects by increasing the antioxidant enzymes GPx 4, SOD1, HO-1, SOD2, and peroxiredoxin 2 in the kidney tissues of the spontaneously hypertensive rats (SHRs) [33]. The authors concluded that the dipeptide showed antioxidative activity through preventing Nrf2 degradation by protein kinase B (Akt) activation and GSK-3 $\beta$ phosphorylation.

\section{Role of Dietary Bioactive Peptides in Obesity}

Obesity is a public health issue worldwide and characterized by excessive body fat accumulation due to the difference between energy intake and energy spending, which enhances the risk of metabolic disorders, namely, type 2 diabetes mellitus (T2DM), hypertension, and cardiovascular disorders $[47,48]$. It is estimated that globally, $18 \%$ men and $21 \%$ women will suffer from obesity by 2025 [49]. Adipocytes are fat cells and the main function of adipocytes is the storage of energy as fat. Preadipocytes differentiate into mature adipocytes through a process known as adipogenesis. Hypertrophy and hyperplasia of adipocytes are two mechanisms that contribute to the obesity and obesity-related metabolic disorders $[50,51]$.

Several recent studies demonstrated that various dietary peptides from soybean, quinoa, common bean, camel whey, spirulina, blue mussel, skate, tuna, Alaska pollock, sardinella, hazelnut, and kefir exhibited antiobesity effects through modulation of multiple molecular mechanisms including the reduction of adipogenesis through downregulation of the expression of peroxisome proliferator-activated receptor(PPAR-) $\gamma$, CCAAT/enhancer binding protein alpha $(\mathrm{C} / \mathrm{EBP}-\alpha)$, sterol regulatory element binding protein(SREBP-) 1, and HMGCR, enhancing lipolysis, reducing body weight (BW) and food intake, inhibiting lipase activity, decreasing the accumulation of triglycerides, and blocking 
TABLE 1: Molecular mechanisms of action of dietary peptides in redox balance.

\begin{tabular}{|c|c|c|c|c|c|c|}
\hline $\begin{array}{l}\text { Dietary } \\
\text { protein source }\end{array}$ & $\begin{array}{l}\text { Enzyme used } \\
\text { to produce } \\
\text { peptides }\end{array}$ & $\begin{array}{l}\text { Peptide sequence or } \\
\text { molecular weight }\end{array}$ & Object & $\mathrm{IC}_{50} / \mathrm{EC}_{50}$ values & $\begin{array}{l}\text { Activity/mechanisms of } \\
\text { action }\end{array}$ & Reference \\
\hline $\begin{array}{l}\text { Ziziphus } \\
\text { jujuba fruits }\end{array}$ & $\begin{array}{l}\text { Papain and } \\
\text { trypsin }\end{array}$ & VGQHTR and GWLK & $\begin{array}{l}\text { DPPH, ABTS, } \\
\text { and metal } \\
\text { chelating assays }\end{array}$ & - & $\begin{array}{c}\text { Peptides scavenged ABTS } \\
\text { and DPPH and showed } \\
\text { strong metal chelating } \\
\text { activity }\end{array}$ & {$[114]$} \\
\hline Corn gluten & Alcalase & $<1 \mathrm{kDa}$ and GLLLPH & $\begin{array}{c}\mathrm{H}_{2} \mathrm{O}_{2} \text {-induced } \\
\text { HepG2 }\end{array}$ & - & $\begin{array}{l}\text { Peptides reduced ROS and } \\
\text { increased SOD, CAT } \\
\text { activities, and GSH levels } \\
\text { and GR activity }\end{array}$ & {$[115]$} \\
\hline $\begin{array}{l}\text { Milk protein } \\
\text { concentrate }\end{array}$ & Trypsin & - & $\begin{array}{l}\text { Healthy and } \\
\text { diabetic rats }\end{array}$ & - & $\begin{array}{l}\text { Peptides enhanced the } \\
\text { activities of CAT, SOD and } \\
\text { reduced glutathione, } \\
\text { glutathione-S-transferase, } \\
\text { and GPx }\end{array}$ & {$[41]$} \\
\hline $\begin{array}{l}\text { Palmaria } \\
\text { palmata } \\
\text { macroalgal } \\
\text { protein }\end{array}$ & Corolase PP & SDITRPGGNM & $\begin{array}{l}\text { ORAC and } \\
\text { FRAP assays }\end{array}$ & - & $\begin{array}{l}\text { Peptide showed strong } \\
\text { oxygen radical absorbance } \\
\text { capacity and ferric- } \\
\text { reducing antioxidant } \\
\text { power activity }\end{array}$ & [116] \\
\hline Rice bran & Trypsin & YSK & $\begin{array}{l}\text { DPPH and } \\
\text { reducing power } \\
\text { assays }\end{array}$ & $\begin{array}{c}\mathrm{DPPH} \mathrm{IC}_{50} 0.15 \\
\mathrm{mg} / \mathrm{mL}\end{array}$ & $\begin{array}{l}\text { Peptide exhibited high } \\
\text { DPPH free radical } \\
\text { scavenging activity and } \\
\text { reducing power }\end{array}$ & {$[1]$} \\
\hline $\begin{array}{l}\text { Nile tilapia } \\
\text { skin gelatin }\end{array}$ & $\begin{array}{l}\text { Ginger } \\
\text { protease }\end{array}$ & GPA & $\begin{array}{l}\mathrm{H}_{2} \mathrm{O}_{2} \text {-induced } \\
\text { IPEC-J2 cell }\end{array}$ & - & $\begin{array}{l}\text { GPA activated the } \\
\text { expression of antioxidant } \\
\text { response element-driven } \\
\text { antioxidant enzyme genes } \\
\text { HO-1, NAD }(\mathrm{P}) \mathrm{H} \text { quinone } \\
\text { oxidoreductase-1, and } \\
\text { glutamyl cysteine ligase } \\
\text { modulator and suppressed } \\
\text { ROS production }\end{array}$ & {$[37]$} \\
\hline $\begin{array}{l}\text { Manchurian } \\
\text { walnut } \\
\text { (Juglans } \\
\text { mandshurica } \\
\text { Maxim.) }\end{array}$ & $\begin{array}{l}\text { Alkaline } \\
\text { protease }\end{array}$ & $<3 \mathrm{kDa}$ & Mice & - & $\begin{array}{l}\text { Peptides increased the } \\
\text { antioxidant capacity by } \\
\text { enhancing SOD, GSH-Px, } \\
\text { and CAT activities and } \\
\text { reducing the MDA content }\end{array}$ & {$[43]$} \\
\hline Soybean & Alcalase & $<3 \mathrm{kDa}$ & $\begin{array}{l}\mathrm{H}_{2} \mathrm{O}_{2} \text {-incuded } \\
\text { oxidative stress } \\
\text { in Caco- } 2 \text { cell } \\
\text { and DPPH } \\
\text { assay }\end{array}$ & $\begin{array}{c}\mathrm{DPPH} \mathrm{IC}_{50} 2.56 \\
\mathrm{mg} / \mathrm{mL}\end{array}$ & $\begin{array}{l}\text { Peptides displayed DPPH } \\
\text { radical scavenging activity } \\
\text { and decreased intracellular } \\
\text { ROS and stimulated the } \\
\text { antioxidant enzymes CAT, } \\
\text { GP, and GR }\end{array}$ & {$[42]$} \\
\hline $\begin{array}{l}\text { Oyster } \\
\text { (Crassostrea } \\
\text { rivularis) } \\
\text { meat }\end{array}$ & Alcalase & $<3 \mathrm{kDa}$ & $\begin{array}{l}\text { Normal male } \\
\text { mice }\end{array}$ & - & $\begin{array}{l}\text { Peptides showed } \\
\text { antioxidant capacity by } \\
\text { increasing the activities of } \\
\text { GSH-Px, SOD, and CAT } \\
\text { and reducing MDA levels }\end{array}$ & {$[44]$} \\
\hline Buffalo casein & - & YFYPQL & $\begin{array}{l}\mathrm{H}_{2} \mathrm{O}_{2} \text { induced } \\
\text { Caco- } 2 \text { cell and } \\
\text { ABTS and } \\
\text { ORAC assays }\end{array}$ & - & $\begin{array}{c}\text { YFYPQL showed } \\
\text { antioxidant and inhibited } \\
\text { ROS generation and } \\
\text { decreased cellular oxidative } \\
\text { products, MDA, and } \\
\text { protein carbonyls and } \\
\text { increased CAT, SOD, and } \\
\text { GPx by stimulating Nrf2 }\end{array}$ & {$[40]$} \\
\hline
\end{tabular}


Table 1: Continued.

\begin{tabular}{|c|c|c|c|c|c|c|}
\hline $\begin{array}{l}\text { Dietary } \\
\text { protein source }\end{array}$ & $\begin{array}{l}\text { Enzyme used } \\
\text { to produce } \\
\text { peptides }\end{array}$ & $\begin{array}{l}\text { Peptide sequence or } \\
\text { molecular weight }\end{array}$ & Object & $\mathrm{IC}_{50} / \mathrm{EC}_{50}$ values & $\begin{array}{l}\text { Activity/mechanisms of } \\
\text { action }\end{array}$ & Reference \\
\hline & & & & & $\begin{array}{l}\text { stress signaling and } \\
\text { scavenged ABTS and } \\
\text { ORAC free radicals }\end{array}$ & \\
\hline $\begin{array}{l}\text { Wheat germ } \\
\text { protein }\end{array}$ & $\begin{array}{c}\text { Alcalase, } \\
\text { pepsin, and } \\
\text { proteinase K }\end{array}$ & $\begin{array}{l}\text { TVGGAPAGRIVME, } \\
\text { VGGIDEVIAK, } \\
\text { GNPIPREPGQVPAY, } \\
\text { SGGSYAD ELVSTAK, and } \\
\text { MDATALHYENQK }\end{array}$ & ABTS assay & - & $\begin{array}{c}\text { Peptides exhibited strong } \\
\text { ABTS radical scavenging } \\
\text { activity }\end{array}$ & [117] \\
\hline $\begin{array}{l}\text { Carp } \\
\text { (Cyprinus } \\
\text { carpio) skin } \\
\text { gelatin }\end{array}$ & Protamex & - & $\begin{array}{l}\text { Healthy adult } \\
\text { Wistar rats }\end{array}$ & - & $\begin{array}{c}\text { Peptides showed } \\
\text { antioxidant activity by } \\
\text { increasing the glutathione } \\
\text { reductase activity }\end{array}$ & {$[118]$} \\
\hline $\begin{array}{l}\text { Sesame } \\
\text { (-icum L.) } \\
\text { seed protein }\end{array}$ & $\begin{array}{l}\text { Alcalase and } \\
\text { trypsin }\end{array}$ & $\begin{array}{c}\text { RDRHQKIG, TDRHQKLR, } \\
\text { MNDRVNQGE, } \\
\text { RENIDKPSRA, } \\
\text { SYPTECRMR, } \\
\text { GGVPRSGEQEQQ, and } \\
\text { AGEQGFEYVTFR }\end{array}$ & $\begin{array}{l}\text { DPPH and } \\
\text { ABTS assays }\end{array}$ & $\begin{array}{c}\mathrm{DPPH} \mathrm{IC}_{50} 0.105 \\
\text { and ABTS IC } \\
0.004 \mathrm{mg} / \mathrm{mL}\end{array}$ & $\begin{array}{l}\text { SYPTECRMR exhibited } \\
\text { the highest DPPH and } \\
\text { ABTS free radical } \\
\text { scavenging antioxidant } \\
\text { activity }\end{array}$ & {$[34]$} \\
\hline Finger millet & Trypsin & $\begin{array}{l}\text { STTVGLGISMRSASVR and } \\
\text { TSSSLNMAVRGGLTR }\end{array}$ & DPPH assay & DPPH $75-80 \%$ & $\begin{array}{l}\text { Peptides exhibited DPPH } \\
\text { and ABTS radical } \\
\text { scavenging activities by } \\
\text { interaction of serine and } \\
\text { threonine residues of } \\
\text { peptides with free radicals }\end{array}$ & [119] \\
\hline Potato & - & Dipeptide IF & SHR rats & - & $\begin{array}{l}\text { Peptides increased the } \\
\text { antioxidant enzymes HO- } \\
1, \text { GPx, SOD, and } \\
\text { peroxiredoxin } 2 \text { through } \\
\text { the Akt pathway to regulate } \\
\text { Nrf2 activity and prevented } \\
\text { Nrf2 degradation by Akt } \\
\text { activation and GSK-3 } \beta \\
\text { phosphorylation }\end{array}$ & {$[33]$} \\
\hline $\begin{array}{l}\text { Mytilus } \\
\text { Coruscus } \\
\text { mussel }\end{array}$ & Trypsin & $<1 \mathrm{kDa}$ & $\begin{array}{l}\mathrm{H}_{2} \mathrm{O}_{2} \text {-induced } \\
\mathrm{HUVEC} \text { and } \\
\mathrm{OH}, \mathrm{O}_{2} \text {, and } \\
\text { ferric-reducing } \\
\text { assays }\end{array}$ & - & $\begin{array}{l}\text { Peptides reduced the } \\
\text { accumulation of ROS and } \\
\text { MDA production and } \\
\text { increased the levels of the } \\
\text { SOD, CAT, and GSH-Px } \\
\text { cellular antioxidant } \\
\text { capacities through } \\
\text { regulating the Nrf2-driven } \\
\text { antioxidant defense } \\
\text { mechanisms. Peptides } \\
\text { showed strong OH, } \mathrm{O}_{2} \\
\text { radical scavenging } \\
\text { activities and ferric- } \\
\text { reducing power }\end{array}$ & {$[46]$} \\
\hline $\begin{array}{l}\text { Mackerel } \\
\text { (Scomber } \\
\text { japonicus) } \\
\text { muscle }\end{array}$ & Protamex & ALSTWTLQLGSTSFSASPM & DPPH assay & DPPH $36.34 \%$ & $\begin{array}{l}\text { Peptide showed strong } \\
\text { DPPH radical scavenging } \\
\text { activity with } 36 \% \\
\text { inhibition }\end{array}$ & {$[120]$} \\
\hline $\begin{array}{l}\text { Soft-shelled } \\
\text { turtle }\end{array}$ & $\begin{array}{l}\text { Neutrase, } \\
\text { papain, } \\
\text { proteinase, } \\
\text { pepsin, and } \\
\text { trypsin }\end{array}$ & EDYGA & HepG2 cells & - & $\begin{array}{l}\text { EDYGA modulated the } \\
\text { Nrf2/ARE pathway by } \\
\text { enhancing the Nrf2 level } \\
\text { via Nrf2 stabilization and } \\
\text { decreasing the level of }\end{array}$ & {$[45]$} \\
\hline
\end{tabular}


Table 1: Continued.

\begin{tabular}{|c|c|c|c|c|c|c|}
\hline $\begin{array}{l}\text { Dietary } \\
\text { protein source }\end{array}$ & $\begin{array}{l}\text { Enzyme used } \\
\text { to produce } \\
\text { peptides }\end{array}$ & $\begin{array}{l}\text { Peptide sequence or } \\
\text { molecular weight }\end{array}$ & Object & $\mathrm{IC}_{50} / \mathrm{EC}_{50}$ values & $\begin{array}{l}\text { Activity/mechanisms of } \\
\text { action }\end{array}$ & Reference \\
\hline $\begin{array}{l}\text { Foxtail millet } \\
(\text { Setaria } \\
\text { italica }) \\
\text { prolamins }\end{array}$ & Alcalase & PFLF and IALLIPF & $\begin{array}{l}\mathrm{H}_{2} \mathrm{O}_{2} \text {-induced } \\
\text { human } \\
\text { keratinocyte } \\
\text { HaCaT cells }\end{array}$ & - & $\begin{array}{l}\text { Keapl and glutamate } \\
\text { residues of EDYGA bound } \\
\text { to the Arg } 415 \text { of Kelch } \\
\text { domain receptor pocket } \\
\text { Peptides decreased the } \\
\text { production of ROS and } \\
\text { MDA and enhanced the } \\
\text { GSH level }\end{array}$ & {$[121]$} \\
\hline Krill & Pepsin & AMVDAIAR & $\begin{array}{c}\mathrm{H}_{2} \mathrm{O}_{2-}^{-} \\
\text {stimulated } \\
\text { hepatocytes }\end{array}$ & $\begin{array}{c}\mathrm{DPPH} \mathrm{IC}_{50} 0.87 \\
\mathrm{mM}\end{array}$ & $\begin{array}{l}\text { Peptide reduced oxidative } \\
\text { stress by enhancing SOD, } \\
\text { CAT, and GPx. Peptide } \\
\text { increased Nrf } 2 \text { and HO-1 } \\
\text { expression and activated } \\
\text { Nrf } 2 / \mathrm{HO}-1 \text { by activating } \\
\text { the ERK pathway }\end{array}$ & {$[38]$} \\
\hline $\begin{array}{l}\text { Watermelon } \\
\text { seed protein }\end{array}$ & Alcalase & RDPEER & $\begin{array}{l}\mathrm{H}_{2} \mathrm{O}_{2} \text {-induced } \\
\text { oxidative stress } \\
\text { in HepG2 cells }\end{array}$ & - & $\begin{array}{l}\text { RDPEER reduced the } \\
\text { oxidative stress by } \\
\text { increasing CAT, SOD, and } \\
\text { GSH-Px, and reducing } \\
\text { MDA production and ROS } \\
\text { accumulation }\end{array}$ & {$[39]$} \\
\hline $\begin{array}{l}\text { Scallop } \\
\text { (Patinopecten } \\
\text { yessoensis) } \\
\text { shellfish }\end{array}$ & $\begin{array}{l}\text { Pepsin, } \\
\text { dispase, and } \\
\text { alcalase }\end{array}$ & $<3 \mathrm{kDa}$ & $\begin{array}{l}\mathrm{DPPH}, \mathrm{HO}^{*} \text {, } \\
\text { and ABTS } \\
\text { assays and } \\
\mathrm{H}_{2} \mathrm{O}_{2} \text {-induced } \\
\text { PC-12 cells }\end{array}$ & $\begin{array}{c}\text { DPPH EC } \mathrm{E}_{50} \\
1.30-2.40, \mathrm{ABTS} \\
\mathrm{EC}_{50} 0.75-1.98, \\
\text { and } \mathrm{OH} \mathrm{EC} \mathrm{EC}_{50} \\
1.07-1.43 \mathrm{mg} / \mathrm{mL}\end{array}$ & $\begin{array}{l}\text { Peptides scavenged the free } \\
\text { radicals of DPPH, HO*, } \\
\text { ABTS, and inhibited ROS } \\
\text { accumulation }\end{array}$ & [122] \\
\hline Milk casein & - & $\begin{array}{c}\text { ARHPHPHLSFM, } \\
\text { AVPYPQR, NPYVPR, and } \\
\text { KVLPVPEK }\end{array}$ & $\begin{array}{l}\text { Peroxide- } \\
\text { induced } \\
\text { oxidative stress } \\
\text { Caco-2 cells }\end{array}$ & - & $\begin{array}{l}\text { Peptides enhanced the } \\
\text { expression of SOD1, Trx1, } \\
\text { TrxR1, GR, and NQO1 by } \\
\text { activating the Keap1-Nrf2 } \\
\text { pathway. Peptides } \\
\text { inhibited the interaction } \\
\text { between Keap1 and Nrf2, } \\
\text { by binding to Nrf2 in the } \\
\text { Keap1 pocket and } \\
\text { increased antioxidant } \\
\text { enzyme expression }\end{array}$ & {$[32]$} \\
\hline $\begin{array}{l}\text { Corn gluten } \\
\text { meal }\end{array}$ & $\begin{array}{l}\text { Fermentation } \\
\text { mice with } \\
\text { Bacillus } \\
\text { subtilis } \\
\text { MTCC5480 } \\
\text { (BS5480) }\end{array}$ & $<10 \mathrm{kDa}$ & Aging rats & - & $\begin{array}{c}\text { Peptides increased } \\
\text { activities of total SOD, } \\
\text { CAT, GPx, and total } \\
\text { antioxidant capacity and } \\
\text { decreased MDA }\end{array}$ & {$[31]$} \\
\hline $\begin{array}{l}\text { Moringa } \\
\text { oleifera seeds }\end{array}$ & $\begin{array}{c}\text { Flavor } \\
\text { protease }\end{array}$ & $\begin{array}{l}\text { GY, PFE, YTR, FG, QY, IN, } \\
\text { SF, SP,YFE, IY, and LY }\end{array}$ & $\begin{array}{l}\mathrm{H}_{2} \mathrm{O}_{2} \text { induced } \\
\text { oxidative } \\
\text { damage in } \\
\text { Chang liver } \\
\text { cells and DPPH } \\
\text { and ABTS } \\
\text { assays }\end{array}$ & $\begin{array}{c}\text { DPPH EC } \mathrm{EC}_{50} \\
0.75-2.28 \mathrm{mg} / \mathrm{mL} \\
\text { and ABTS EC } \\
0.32-1.03 \mathrm{mg} / \mathrm{mL}\end{array}$ & $\begin{array}{l}\text { Peptides exhibited strong } \\
\text { scavenging activities on } \\
\text { free radicals DPPH and } \\
\text { ABTS }^{+} \text {. SF and QY } \\
\text { scavenged ROS by } \\
\text { increasing SOD and CAT } \\
\text { and reducing MDA }\end{array}$ & {$[25]$} \\
\hline Ginger & $\begin{array}{l}\text { Pepsin and } \\
\text { trypsin }\end{array}$ & VTYM & $\begin{array}{l}\text { DPPH and } \\
\text { ABTS assays }\end{array}$ & $\begin{array}{c}\mathrm{EC}_{50} \text { of } \mathrm{DPPH} \\
19.9 \pm 2.1 \text { and } \\
\mathrm{ABTS} 24.0 \pm 3.7 \\
\mu \mathrm{mol} / \mathrm{L}\end{array}$ & $\begin{array}{l}\text { VTYM showed potent } \\
\text { DPPH and ABTS radical } \\
\text { scavenging activity }\end{array}$ & {$[9]$} \\
\hline
\end{tabular}


TABLE 1: Continued.

\begin{tabular}{|c|c|c|c|c|c|c|}
\hline $\begin{array}{l}\text { Dietary } \\
\text { protein source }\end{array}$ & $\begin{array}{l}\text { Enzyme used } \\
\text { to produce } \\
\text { peptides }\end{array}$ & $\begin{array}{l}\text { Peptide sequence or } \\
\text { molecular weight }\end{array}$ & Object & $\mathrm{IC}_{50} / \mathrm{EC}_{50}$ values & $\begin{array}{c}\text { Activity/mechanisms of } \\
\text { action }\end{array}$ & Reference \\
\hline $\begin{array}{l}\text { Snakehead } \\
\text { (Channa } \\
\text { argus) soup }\end{array}$ & $\begin{array}{l}\text { Pepsin and } \\
\text { pancreatin }\end{array}$ & $\begin{array}{c}\text { IVLPDEGK, } \\
\text { PGMLGGSPPGLLGGSPP, } \\
\text { SDGSNIHFPN, and } \\
\text { SVSIRADGGEGEVTVFT }\end{array}$ & $\begin{array}{c}\text { DPPH and } \mathrm{Fe}^{2+} \\
\text { chelating assays } \\
\text { and } \mathrm{H}_{2} \mathrm{O}_{2} \\
\text { induced HepG2 } \\
\text { cells }\end{array}$ & $\begin{array}{c}\mathrm{DPPH} \mathrm{IC}_{50} 1.39 \\
\mathrm{mM} \text { and } \mathrm{Fe}^{2+} \\
\text { chelating ability } \\
\mathrm{IC}_{50} 4.60 \mathrm{mM}\end{array}$ & $\begin{array}{l}\text { Peptides exhibited strong } \\
\text { DPPH and } \mathrm{Fe}^{2+} \text { chelating } \\
\text { ability and molecular } \\
\text { docking indicated that } \\
\text { peptides can bind to the } \\
\text { active site of Keap1 and } \\
\text { thereby activate the cellular } \\
\text { antioxidation Keap1-Nrf2 } \\
\text { pathway }\end{array}$ & \\
\hline $\begin{array}{l}\text { Silver carp } \\
\text { muscle }\end{array}$ & $\begin{array}{l}\text { Papain and } \\
\text { alcalase }\end{array}$ & $<1 \mathrm{kDa}$ and LVPVAVF & $\begin{array}{l}\mathrm{H}_{2} \mathrm{O}_{2} \text { induced } \\
\text { oxidative stress } \\
\text { Caco- } 2 \text { cells } \\
\text { and DPPH } \\
\text { assay }\end{array}$ & $\begin{array}{c}\mathrm{DPPH} \mathrm{EC}_{50} 0.65 \\
\mathrm{mg} / \mathrm{mL}\end{array}$ & $\begin{array}{l}\text { Peptides showed } \\
\text { antioxidant activity by } \\
\text { enhancing the activity of } \\
\text { SOD, CAT, and GSH-Px } \\
\text { and reduced ROS and } \\
\text { showed strong DPPH } \\
\text { scavenging activity }\end{array}$ & {$[12]$} \\
\hline
\end{tabular}

ARE: antioxidant response element; ATBS: 2,2' -azino-bis (3-ethylbenzothiazoline-6 sulphonic acid) diammonium salt; Akt: protein kinase B; CAT: catalase; DPPH: 2,2-diphenyl-1-picrylhydrazyl; ERK: extracellular signal-regulated kinases; FRAP: ferric reducing antioxidant power; GPx: glutathione peroxidase; GSH: glutathione; GR: glutathione reductase; $\mathrm{H}_{2} \mathrm{O}_{2}$ : hydrogen peroxide; $\mathrm{HO}-1$ : heme oxygenase $1 ; \mathrm{IC}_{50}$ : $50 \%$ inhibitory concentration; ROS: reactive oxygen species; SHR: spontaneously hypertensive rats; SOD: superoxide dismutase; MDA: malondialdehyde; NQO1: NAD(P)H quinine dehydrogenase 1; Nrf2: nuclear factor erythroid 2-related factor; HUVEC: human umbilical vein endothelial cells; Keap 1: Kelch-like ECH-associated protein 1; HO: heme oxygenase; Trx1: thioredoxin 1; TrxR1: thioredoxin reductase 1; ORAC: oxygen radical absorbance capacity.

lipogenesis by reducing the fatty acid synthase $[2,10,52,53]$. Various molecular mechanisms of antiobesity peptides are shown in Table 2.

During maturation of preadipocytes into adipocytes, several transcriptional factors are involved. PPAR and C/EBP are two transcription factors that stimulate adipocyte differentiation [50]. Lipid and carbohydrate metabolism is regulated by the PPARs. SREBP1 is a lipogenic transcription factor upon activation by PPAR- $\gamma$ which promotes the adipogenesis and lipogenesis. SREBP1 stimulates lipoprotein lipase and fatty acid synthase and thereby enhances the lipid accumulation in the adipocytes [50]. Therefore, inhibition of the PPARs, C/EBP, and SREBP1 transcriptional factors involved the adipogenesis and lipogenesis using dietaryderived BPs is an efficient approach in the prevention or treatment of obesity and related diseases. It has been revealed that numerous dietary peptides from soy bean, quinoa, hazelnut, canola, tuna, ark shell, and blue mussel showed antiobesity activities by inhibiting the expression of PPAR- $\gamma, \mathrm{C} / \mathrm{EBP}$, and SREBP1 transcriptional factors $[10,51,54]$.

It was found that the antiobesity effects of dietary BPs are related to the peptide sequence, length, composition, and protein source [13]. Peptides with $<1 \mathrm{kDa}$ from blue mussel by pepsin hydrolysis exhibited antiobesity effects by enhancing lipolysis and downregulating adipogenic transcription factors, such as PPAR- $\gamma, \mathrm{C} / \mathrm{EBP}-\alpha$, and SREBP1 [10]. An antiobesity pentapeptide RLLPH was isolated from alcalase hydrolysate of hazelnut (Corylus heterophylla Fisch) and found that the pentapeptide could decrease adipogenesis through reducing the expression of PPAR- $\gamma$, C/EBP- $\alpha$, SREBP-1c, adipocyte protein (aP2), FAS, acetyl-CoA carboxylase 1 (ACC1), and HMGCR in 3T3-L1 adipocytes [13].
Additionally, the authors indicated that the hydrophobic AAs, proline, and leucine, of the peptide, might have contributed to the antiobesity effects of the peptides. Peptides with more hydrophobic AAs can easily penetrate the cell membrane and increase lipid solubility. In a study, peptides $<1$ $\mathrm{kDa}$ from ark shell (Scapharca subcrenata) protein inhibited intracellular lipid buildup and enhanced the lipolysis [51]. The authors were also demonstrated that ark shell peptides inhibited adipogenesis by decreasing the expressions of PPAR- $\gamma$, C/EBP- $\alpha$, SREBP-1c, lipoprotein lipase, and FAS in mouse mesenchymal stem cells. Moreover, the expression of PPAR $-\gamma, \mathrm{C} / \mathrm{EBP}-\alpha$, and aP2 was decreased by tuna skin collagen-derived peptides in obese mice, which resulted in the decrease of adipocyte size [55].

In addition to the downregulation of vital transcriptional factors (PPAR- $\gamma$, C/EBP- $\alpha$, and SREBP-1c) of adipogenesis, several in vivo studies demonstrated that the antiobesity activity of dietary peptides is due to the decrease of BW and food consumption. Oral administration of peptides (10 $\mathrm{mg} / \mathrm{mL}$ ), produced from smooth hound (Mustelus mustelus) muscle by alkaline crude enzyme from $M$. mustelus intestines, for 21 days reduced the BW and food intake in rats [5]. The authors suggested that BW reduction was probably due to the regulation of appetite. The antiobesity effect of Alaska pollack-derived peptides was investigated, and it was found that peptide administration (100 or $300 \mathrm{mg} / \mathrm{kg} \mathrm{BW}$ ) to rats for 3 days decreased the weight of white adipose tissue and reduced the food intake [56]. The authors suggested that the decrease in food intake and white adipose tissue weight of rats after peptide treatment was due to downregulation/suppression of gene expressions of neuropeptide- $Y$ and agoutirelated peptide in hypothalamus, which may reduce the 


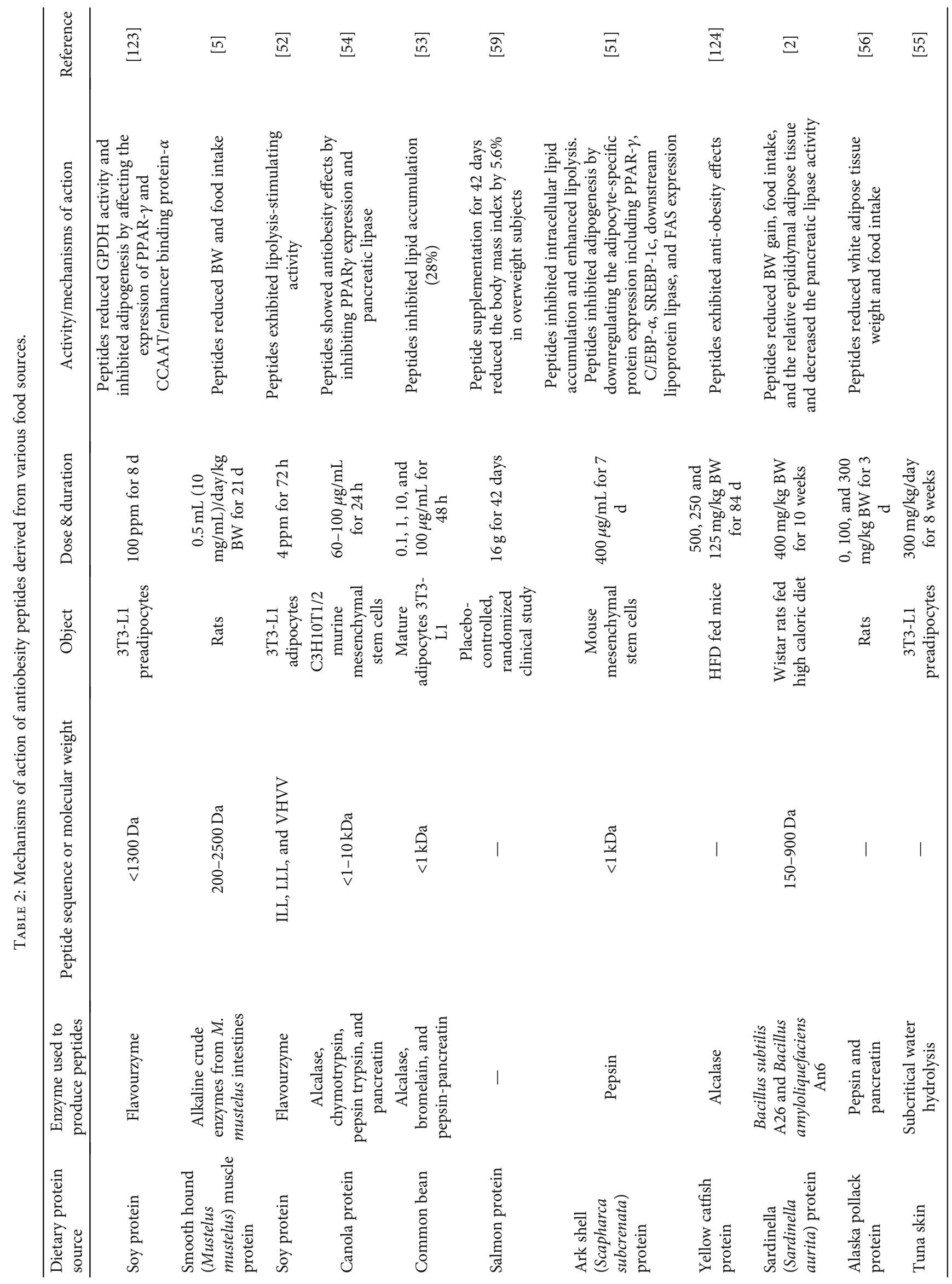




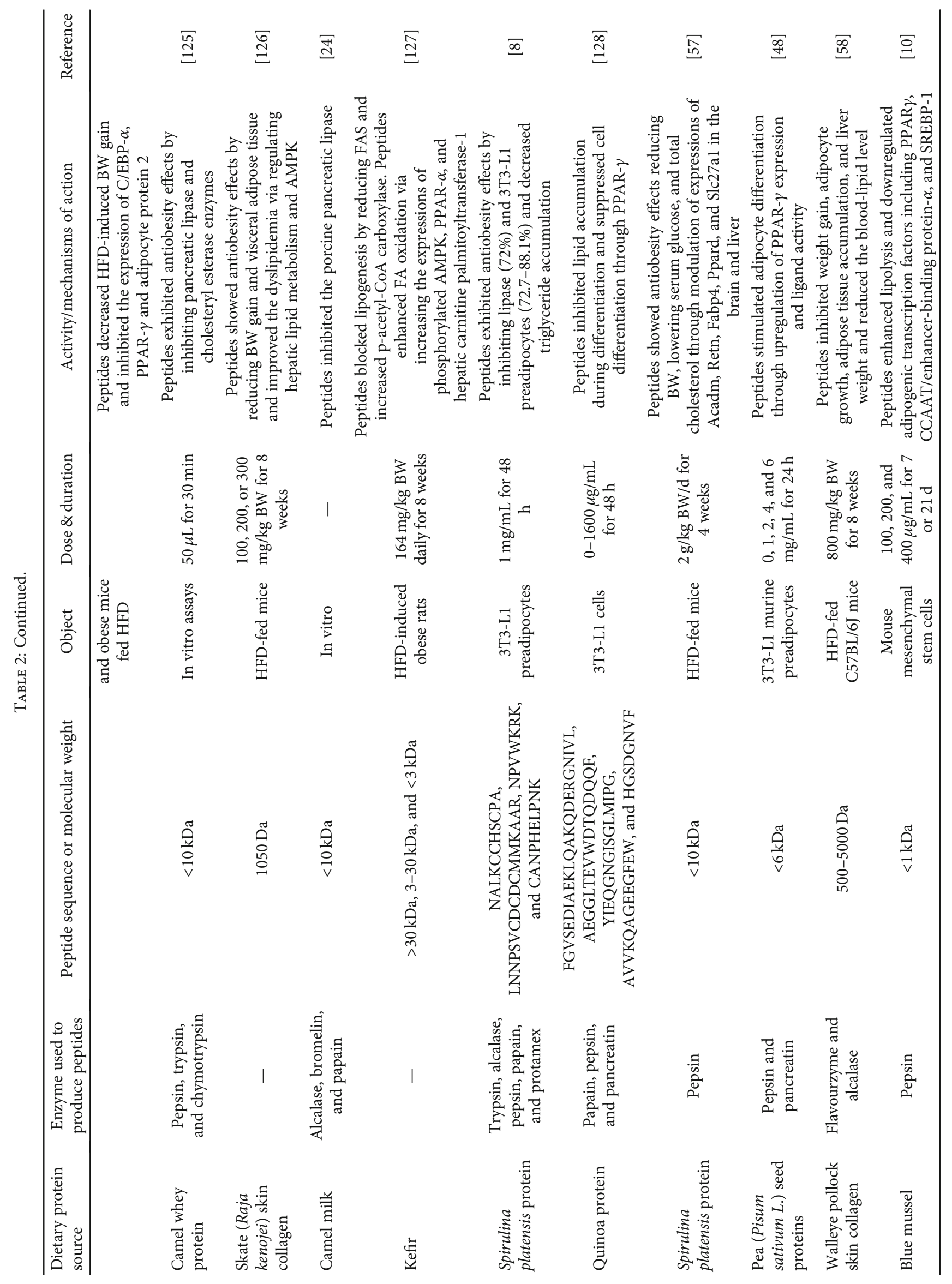




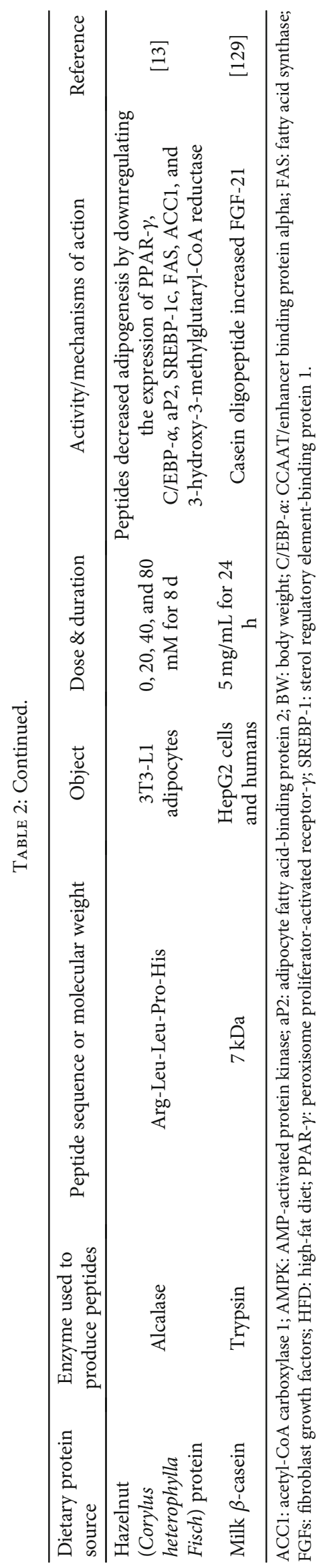


appetite. In a study, it was found that antiobesity effects of sardinella- (Sardinella aurita-) derived peptides were mediated by reducing the BW gain, food intake, and the relative epididymal adipose tissue weight in Wistar rats after 10 weeks of peptide treatment [2]. It was demonstrated that Spirulina platensis-derived peptides exhibited antiobesity effects by reducing BW (39.8\%) and lowering serum glucose (23.8\%) through altering the gene expressions of Acadm, Retn, Fabp4, Ppard, and Slc27a1 in the brain and liver of mice fed with peptides ( $2 \mathrm{~g} / \mathrm{kg}$ BW) for 4 weeks [57]. Recently, it was reported that walleye pollock skin collagenderived peptides considerably reduced the BW gain in obese mice after 8 weeks of peptide treatment [58]. The authors also pointed that peptides inhibited the growth of adipocytes and the accumulation of adipose tissue in obese mice. Furthermore, in a placebo-controlled, randomized clinical investigation, salmon fish-derived peptide supplementation (16 $\mathrm{g} / \mathrm{d}$ ) for 42 days notably decreased (5.6\%) the BMI in obese humans [59].

Pancreatic lipase is an important enzyme that aids in the hydrolysis of dietary fat in the small intestine. Therefore, inhibition of pancreatic lipase is an efficient approach in the management and treatment of being overweight and obesity $[2,24]$. Apart from inhibition of adipogenesis and lipogenesis, some dietary peptides exhibited pancreatic lipase inhibitory activity. Peptides produced from camel milk by using alcalase-, bromelin-, and papain-inhibited porcine pancreatic lipase [24]. It was also found that sardinella peptide administration to rats for 10 weeks decreased the pancreatic lipase activity [2].

\section{The Role of Dietary Bioactive Peptides in Diabetes Mellitus}

Diabetes mellitus (DM) is a complex metabolic disorder with increased blood sugar levels and T2DM accounts for $90 \%$ of diabetes patients. T2DM results from insulin resistance (cells less responsive to the insulin actions) and/or insufficient insulin production from pancreatic beta cells. Obesity $\left(\mathrm{BMI} \geq 30 \mathrm{~kg} / \mathrm{m}^{2}\right)$ has been reported to greatly increase the risk of developing T2DM [60]. Uncontrolled T2DM can cause severe complications such as high blood pressure, stroke, heart attack, atherosclerosis, retinopathy, nephropathy, neuropathy, and dementia.

Recently, several peptides derived from a variety of dietary protein sources including egg white, whey, casein, egg yolk, rice bran, quinoa, soybean, wheat, corn, black bean, oat globulin, walnut, potato, common bean, millets, spirulina, bovine, porcine, Atlantic cod, Atlantic salmon, halibut skin, Styela clava, boarfish, tilapia skin, largemouth bass, zebra blenny, blue whiting, and sea cucumber have shown antidiabetic effects by altering several molecular mechanisms of diabetes such as inhibition of enzymes including $\alpha$-amylase, dipeptidyl peptidase- (DPP-) IV, and $\alpha$-glucosidase; reduction of FBG and $\mathrm{HbA1C}$; enhancement of HOMA-IR; stimulation of secretion of glucagon-like polypeptide-1 (GLP-1) and insulin levels; upregulation of phosphatidylinositol 3-kinase (PI3K), p-GSK-3 $\beta$, p-Akt, and glucose transporter (GLUT)2/4 signaling pathways; blocking of glucose transporters GLUT2 and SGLT1; decreasing of the activation of p38 and c-Jun N-terminal kinase (JNK)1/2; enhancement of the stimulation of insulin receptor substrate-1 (IRS-1) tyrosine residue and Akt; and decreasing of gluconeogenesis through activation of IRS-1/PI3K/Akt and AMP-activated protein kinase (AMPK) [6, 21, 61-64]. The isolated peptide sequences and molecular mechanisms of dietary antidiabetic peptides are shown in Table 3.

$\alpha$-Amylase is an important enzyme in the carbohydrate digestion that breaks down $\alpha$-1,4 glycosidic linkages of starch and produces oligosaccharides. $\alpha$-Glucosidase is present in the brush borders of the small intestine and hydrolyzes the disaccharides and starch to glucose by acting upon $\alpha(1 \rightarrow 4)$ glycosidic bonds. Therefore, inhibition of $\alpha$-amylase and $\alpha$ glucosidase prevents carbohydrate digestion and thus diminishes the postprandial increase of blood glucose. Several chemical $\alpha$-glucosidase and $\alpha$-amylase inhibitors (acarbose, voglibose, and miglitol) have been in use for the management and treatment of T2DM [65]. However, side effects associated with these inhibitors limited their use [63]. Recently, many peptides isolated from several food sources including egg white, corn, oat, egg yolk, spirulina, quinoa, soybean, Phaseolus vulgaris, and zebra blenny have exhibited $\alpha$-amylase and $\alpha$-glucosidase inhibitory activities [61, 62, 66, 67]. Egg white albumin was hydrolyzed using alcalase, and a pentapeptide KLPGF was isolated with $\alpha$-glucosidase $(50 \%$ inhibitory concentration $\left(\mathrm{IC}_{50}\right) 59.5 \mu \mathrm{mol} / \mathrm{L}$ ) and $\alpha$-amylase (IC I0 $120 \mu \mathrm{M})$ inhibitory activities [66]. Three peptides, GVPMPNK, LRSELAAWSR, and RNPFVFAPTLLTVAAR, were extracted from spirulina platensis, and it was found that peptide LRSELAAWSR strongly inhibited $\alpha$-amylase with $\mathrm{IC}_{50}$ of $313.6 \mu \mathrm{g} / \mathrm{mL}$ and $\alpha$-glucosidase with $\mathrm{IC}_{50}$ of 134.2 $\mu \mathrm{g} / \mathrm{mL} \quad[68]$. A $\alpha$-glucosidase inhibitory peptide, LAPSLPGKPKPD, was identified from egg yolk hydrolysate produced by proteinase from Asian pumpkin with an $\mathrm{IC}_{50}$ value of $1065.6 \mu \mathrm{mol} / \mathrm{L}$ [67]. Three peptides, LLPLPVL, SWLRL, and WLRL, produced from soy protein showed $\alpha$ glucosidase inhibitory activity with $\mathrm{IC}_{50} 162.2-237.4 \mu \mathrm{mol} / \mathrm{L}$ [63]. A study reported isolation of $\alpha$-glucosidase inhibitory peptide, QHPHGLGALCAAPPST, from quinoa with an $\mathrm{IC}_{50}$ of $1.0-1.45 \mathrm{mg} / \mathrm{mL}$ [62]. Recently, corn germ protein was hydrolyzed by using alcalase, trypsin, and flavourzyme and it was found that the peptide fraction $(2-10 \mathrm{kDa})$ showed strong $\alpha$-amylase inhibition (71.3\%) and $\alpha$-glucosidase inhibition (37.1\%) activities [61].

Another strategy for the management and treatment of T2DM is to inhibit the DPP-IV that degrades and inactivates incretin hormones, namely, glucose-dependent insulinotropic peptide (GIP) and GLP-1. Therefore, inhibition of DPPIV by dietary-derived BPs can enhance the half-life of GLP1 and thereby increase the release of glucose-dependent insulin from pancreatic cells [61]. For inhibition of DPP-IV activity, several synthetic drugs such as saxagliptin, linagliptin, sitagliptin, and vildagliptin are presently used. However, side effects (diarrhea, nausea, stomach pain, headache, and sore throat) associated with these drugs have forced researches to search for DPP-IV inhibitors from natural dietary sources without any side effects [69]. Many recent studies have reported that dietary protein-derived peptides are an 


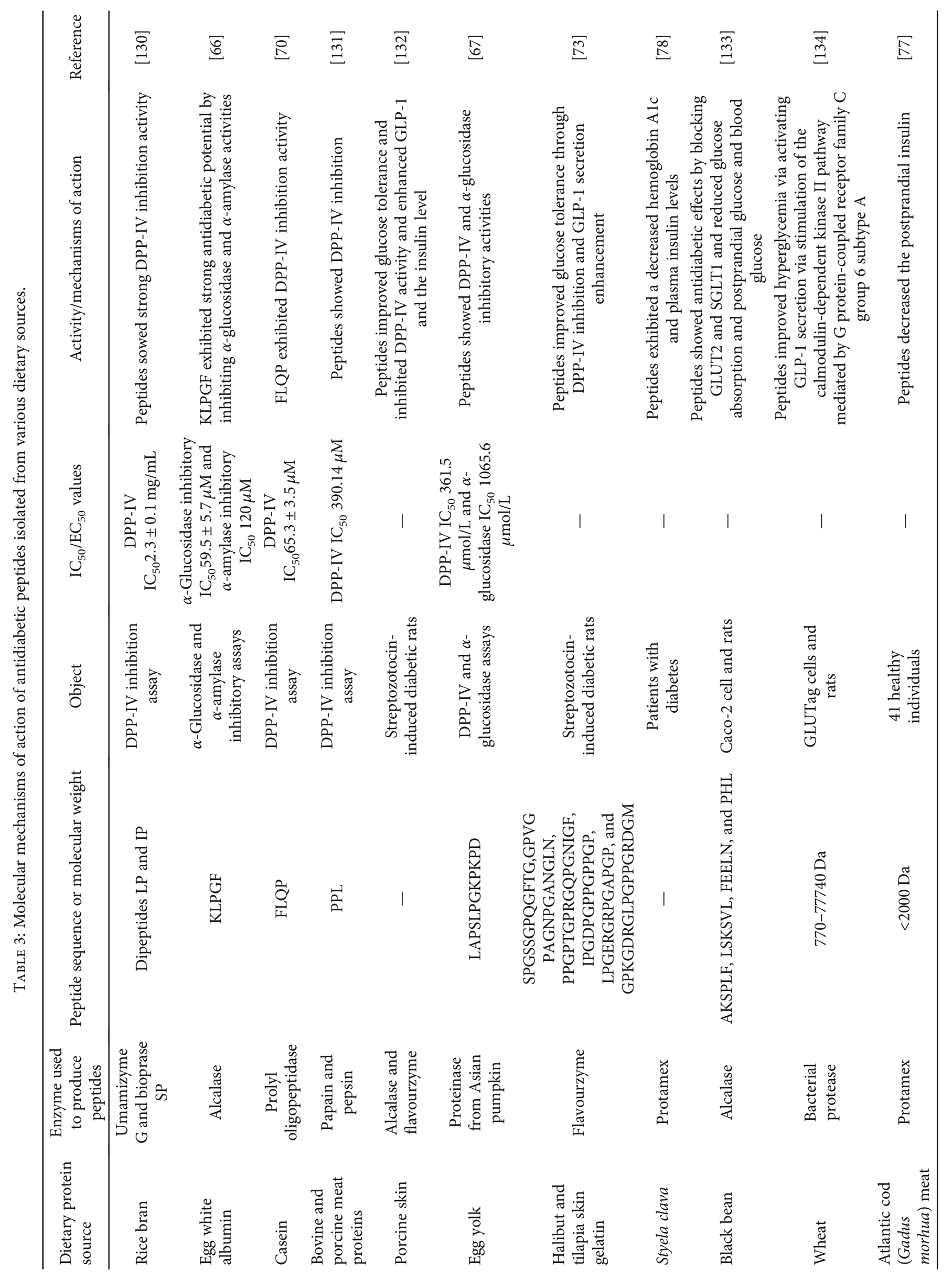




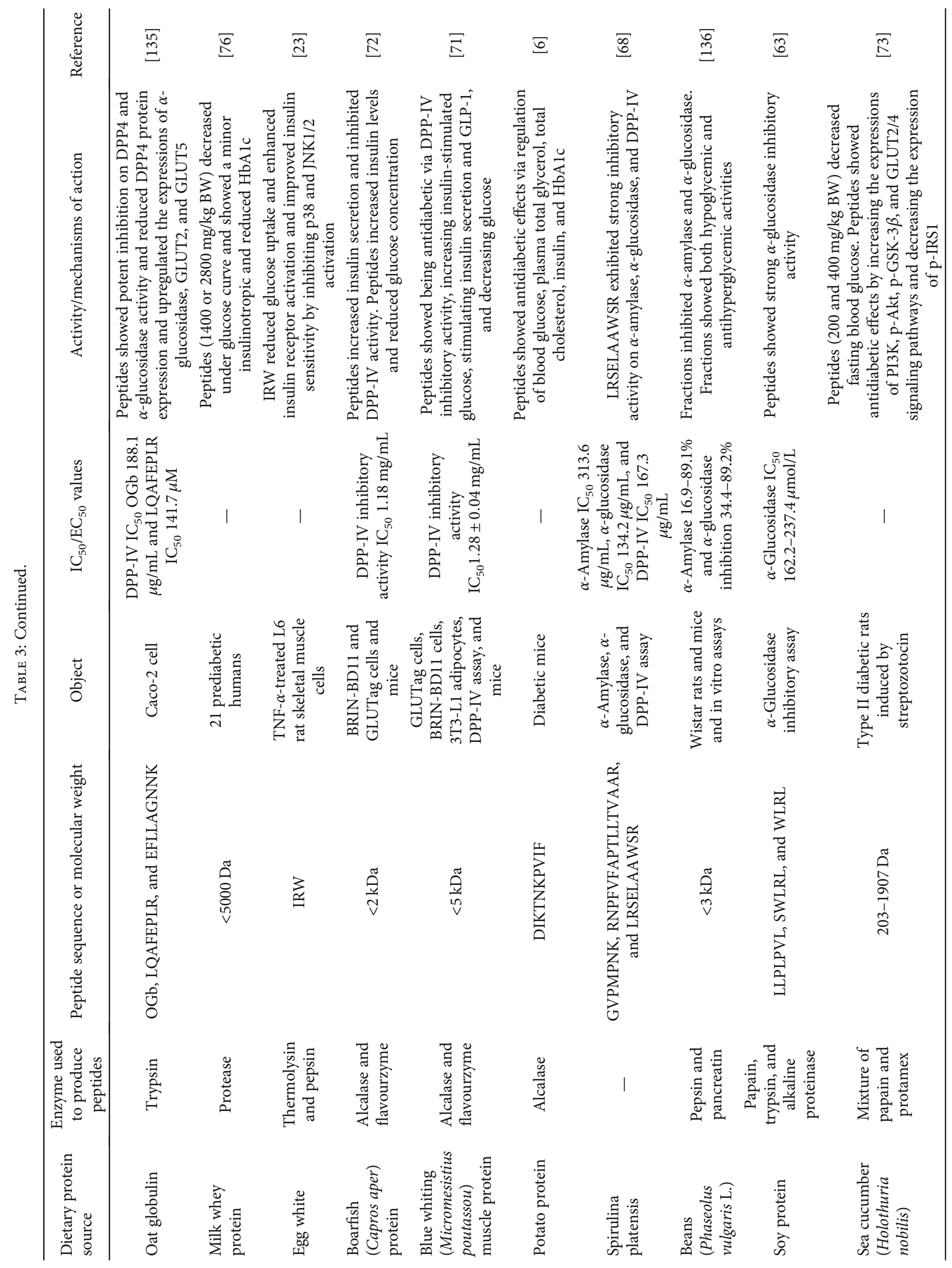




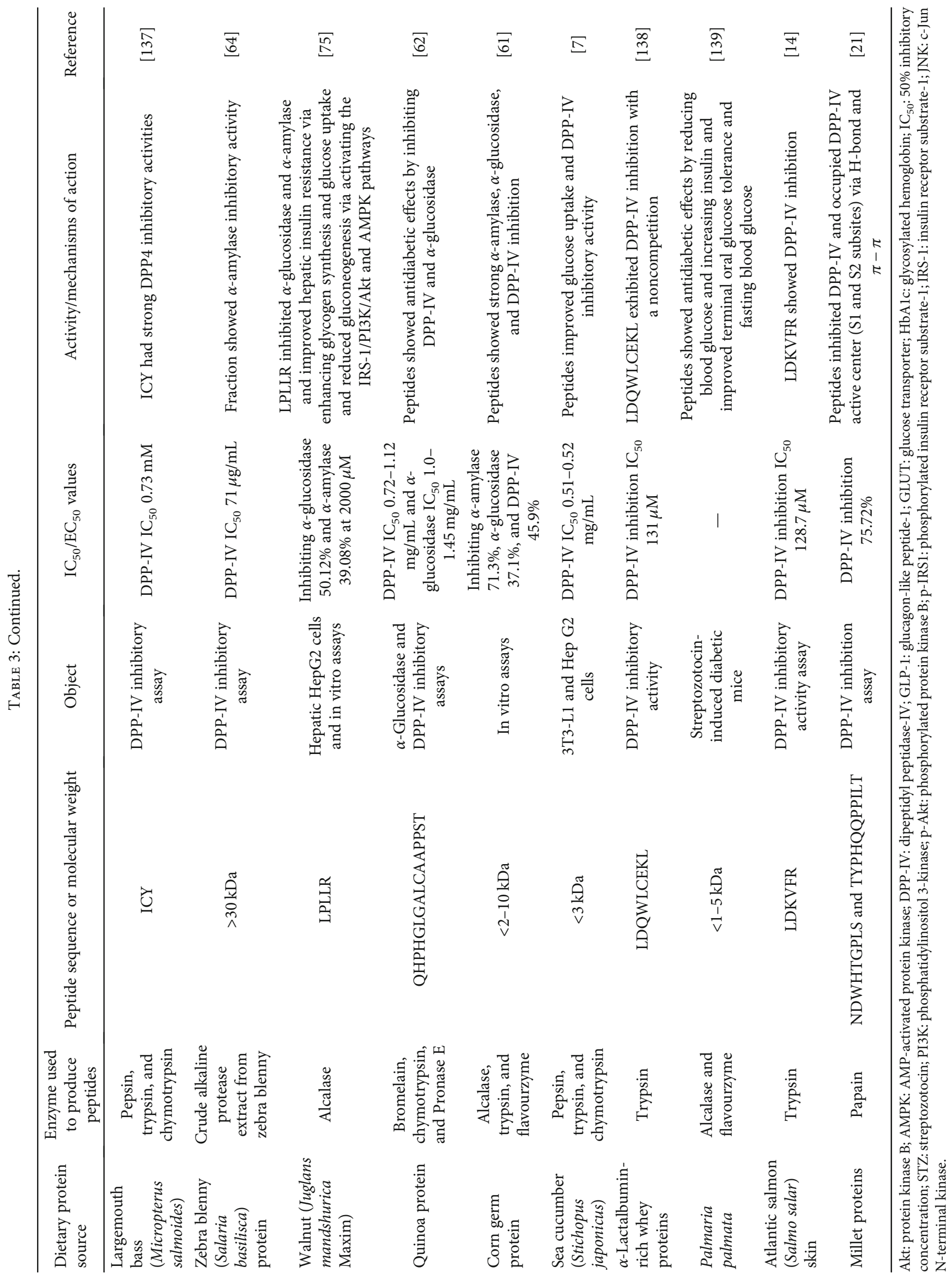


excellent source of DPP-IV inhibitors. Peptides obtained from millet, corn, quinoa, egg yolk, oat, whey, casein, Spirulina platensis, porcine, Atlantic salmon, sea cucumber, largemouth bass, blue whiting, and Capros aper inhibited the DPP-IV activity [67, 70-72]. It has been found that dietary peptides inhibit DPP-IV through attaching the peptides to the active sites of DPP-IV via hydrogen bonds and hydrophobic interactions and thereby prevent the enzyme action $[14,21]$. Two peptides NDWHTGPLS and TYPHQQPPILT derived from papain hydrolysates of millet proteins inhibited DPP-IV activity (75\%) [21]. It was demonstrated that both the peptides inhibited DPP-IV activity by occupying the active sites of DPP-IV via hydrogen and pi bonds. In a recent study, Atlantic salmon skin was hydrolyzed by using trypsin and isolated a new DPP-IV inhibitory peptide, LDKVFR, with $\mathrm{IC}_{50}$ of $128.7 \mu \mathrm{M}$ [14]. Additionally, it was found that $6 \mathrm{H}$ bonds and 8 hydrophobic interactions played a significant role in the inhibition of DPPIV by LDKVFR. A peptide, LDQWLCEKL, obtained from trypsin hydrolysate of $\alpha$-lactalbumin-rich whey proteins inhibited DPP-IV $\left(\mathrm{IC}_{50} 131 \mu \mathrm{M}\right)$ through a noncompetitive mode of inhibition.

The PI3K/Akt signaling pathway regulates the glucose uptake. When cells are resistant to insulin, glucose uptake is impaired in the liver and skeletal muscles. Insulin activates IRS after binding to IRS and the activated IRS phosphorylates IRS-1. Phosphorylation of IRS-1 results in the activation of PI3K. The activated PI3K phosphorylates Akt, and the activated Akt helps in the migration of intracellular GLUT2/4 to the plasma membrane and therefore increases the glucose absorption into cells. But insulin resistance weakens the PI3K/Akt signaling pathway [73, 74]. Hence, stimulation of the PI3K/Akt molecular pathway is an efficient approach in the management of insulin resistance. In a study, the authors hydrolyzed walnut protein using alcalase and isolated an antidiabetic peptide LPLLR with a molecular weight of 610.4 Da. The authors reported that the identified peptide improved hepatic insulin resistance (IR) through enhancing glycogen synthesis and glucose uptake and reducing gluconeogenesis via activating the IRS-1/PI3K/Akt and AMPK signaling pathways in hepatic HepG2 cells [75]. Two hundred forty-two peptides, with a molecular weight ranging from 203 to $1907 \mathrm{Da}$, were isolated from the hydrolysate of sea cucumber and found that the peptides showed antidiabetic effects by upregulation of PI3K, p-Akt, p-GSK-3 $\beta$, and GLUT2/4 signaling pathways, while decreasing p-IRS1 expression in diabetic rats [73].

In addition to the peptides described above, the antidiabetic activities of dietary peptides have also been investigated in human subjects. In a randomized and crossover clinical trial, whey peptide $(<5000 \mathrm{Da})$ ( 1400 or $2800 \mathrm{mg} / \mathrm{kg} \mathrm{BW}$ ) administration to 21 prediabetic human subjects decreased under the curve (iAUC) of glucose as well as showed a minor insulinotropic effect and reduced HbAlc [76]. A doubleblind crossover clinical trial conducted using peptides $(<2000 \mathrm{Da})$ derived from Atlantic cod showed that a single dose of $20 \mathrm{mg} / \mathrm{kg}$ BW considerably decreased the postprandial insulin in 41 healthy individuals [77]. Moreover, peptides derived from Styela clava have also been shown to decrease the hemoglobin A1c and plasma insulin levels after 4 weeks of administration in patients with T2DM [78].

\section{The Role of Dietary Bioactive Peptides in Hypertension}

Hypertension is an important risk factor that can increase the chance of developing heart attack or stroke. Clinically, systolic blood pressure (SBP) $140 \mathrm{mmHg}$ or above and/or DBP $90 \mathrm{mmHg}$ or above are considered as hypertension [79]. It is estimated that over a billion people ( 1 in 5 women and 1 in 4 men) are suffering from hypertension.

Food-derived peptides play a significant role in the prevention of hypertension. Recently, numerous antihypertensive peptides are isolated from different food sources such as milk [80], casein [81, 82], egg white ovotransferrin [22], rice bran [1], wheat [83], soybean [84], potato [85], turmeric and ginger [9], quinoa [62], black cumin [86], coix [87], pistachio [88], hazelnut [89], mung bean [90], lentil [91], seahorse [92], egg white from ostrich [93], chum salmon [94], skate [95], cuttlefish [96], Sipuncula [97], bighead carp [98], shrimp (Pandalus borealis) [79], and beef [99]. The isolated dietary protein-derived peptides have been demonstrated to exhibit antihypertensive activities through influencing various molecular mechanisms including inhibition of angiotensin-converting enzyme (ACE), reduction of SBP, decrease of angiotensin II levels and AT1R expression, enhancing vasodilation, improving central blood pressure and arterial stiffness, and inhibition of vasoconstriction via PPAR- $\gamma$ expression $[9,79,84,90]$. Table 4 shows the molecular mechanisms of antihypertensive peptides isolated from various dietary sources.

Human blood pressure is regulated by ACE (EC 3.4.15.1). ACE cleaves the dipeptide, HL, from angiotensin I and converts the inactive angiotensin I into angiotensin II and thereby enhances the blood pressure. Angiotensin II is a powerful vasoconstrictor, and ACE inactivates the bradykinin, which is a potent vasodilator. Therefore, inhibition of $\mathrm{ACE}$ is an important molecular target in the prevention and management of hypertension. Currently, several peptide drugs, namely, captopril, lisinopril, and enalapril, are used as ACE inhibitors for the management of high blood pressure $[80,97,100]$. Due to the side effects (cough, fatigue, dizziness, headaches, and loss of taste) associated with these synthetic drugs, there is an increasing interest to search for safe ACE inhibitors from natural food sources. Various food sources are an excellent source of ACE inhibitory peptides. Most dietary ACE inhibitory peptides contained 3-15 AA residues. Recently, several peptides have been isolated with ACE inhibitory activity from numerous dietary sources such as milk [80], casein [82], egg white [93], soybean [84], rice bran [1], wheat [83], pistachio [88], potato and rapeseed [85], turmeric and ginger [9], quinoa [62], black cumin [86], hazelnut [89], lentil [91], seahorse [92], chum salmon [94], skate [95], cuttlefish [96], Sipuncula [97], bighead carp [98], and beef [99].

It has been demonstrated that hydrogen bonds play a vital role in the binding of BPs to the ACE catalytic pocket and thereby facilitate ACE inhibition. Three ACE inhibitory peptides, LLSGTQNQPSFLSGF, NSLTLPILRYL, and 
TLEPNSVFLPVLLH, were isolated from lentil seeds with $\mathrm{IC}_{50}$ of $44-120 \mu \mathrm{M}$, and it was found that the peptides inhibited ACE through interactions by hydrogen bonds with three residues of the ACE catalytic site [91]. A tripeptide YSK with ACE inhibition was identified from trypsin hydrolysate of rice bran, and ACE inhibition of YSK was due to the formation of hydrogen bonds with the binding site of ACE [1]. The molecular interactions between dipeptide, $\mathrm{YV}$, obtained from ostrich egg white and ACE were studied and it demonstrated that YV inhibited ACE ( $\mathrm{IC}_{50} 63.97 \mu \mathrm{g} / \mathrm{mL}$ ) by binding to $\mathrm{S} 1$ and S2 pocket sites of ACE through hydrogen bonds [93]. A pentapeptide, ACKEP, purified from pistachio kernel hydrolysates was shown to inhibit ACE ( IC $_{50} 126 \mu \mathrm{M}$ ) by binding with seven AAs of the ACE catalytic site (His383, His387, Glu384, Arg522, Asp358, Ala356, and Asn70) and two atoms of ACKEP [88]. In a study, three ACE inhibitory peptides, AVKVL, YLVR, and TLVGR, were identified from alcalase hydrolysate of hazelnut. The authors found that all the three peptides exhibited ACE inhibition $\left(\mathrm{IC}_{50} 5.42-\right.$ $249.3 \mu \mathrm{M})$ via a noncompetitive inhibition through the formation of cation-pi interactions [89]. In another study, four ACE inhibitory peptides, EDEVSFSP, SRPFNL, RSPFNL, and ENPFNL, were purified from fermented soybean with $\mathrm{IC}_{50}$ of $0.131-0.811 \mathrm{mg} / \mathrm{mL}$ [84]. It was suggested that the $\mathrm{N}$-terminal sequence and the location of AAs in the peptides play an essential role in ACE inhibition. Recently, a peptide, VTPVGVPK, produced by $\alpha$-chymotrypsin hydrolysis from black cumin seed was shown to inhibit ACE ( $\left.\mathrm{IC}_{50} 1.8 \mu \mathrm{M}\right)$ through a noncompetitive inhibition [86]. A peptide, QHPHGLGALCAAPPST, identified from chymotrypsin hydrolysate of quinoa inhibited ACE by binding to the number of active hotspots of the ACE enzyme [62]. Moreover, two peptides, SAGGYIW and APATPSFW, were isolated from wheat gluten with ACE inhibition of $\mathrm{IC}_{50}$ 0.002-0.036 $\mathrm{mg} / \mathrm{mL}$ [83]. The authors concluded that two peptides with proline and negatively charged residues inhibited ACE through the modulation of ionic and hydrophobic connections of the ACE active site.

In addition to ACE inhibition, several in vivo studies (animal and human) have reported the blood pressurelowering effects of numerous peptides isolated from various food sources. Peptides, SLVSPSAAAAAAPGGS and KKRSKKKSFG, generated from potato and rapeseed were found to reduce $(154.7 \mathrm{mmHg})$ the mean arterial blood pressure of treated rats compared to the control $(177 \mathrm{mmHg})$ group [85]. Two antihypertensive peptides, IQW and LKP, were identified from thermolysin and pepsin hydrolysates prepared from egg white ovotransferrin and demonstrated that tripeptide (IQW and LKP) administration reduced the mean blood pressure by 19 and $30 \mathrm{mmHg}$, respectively, compared to control SHRs [22]. Administration of a peptide, VELYP, produced from Sepia officinalis muscle, to SHR exhibited antihypertensive effects by decreasing SBP [96]. In a study, a beef myofibrillar protein-derived peptide LIVGIIRCV at 400 and $800 \mathrm{mg} / \mathrm{kg}$ BW decreased SBP by 28 and $35 \mathrm{mmHg}$ in SHRs, respectively [99]. A randomized and double-blind human trial conducted on level 1 hypertensive patients demonstrated that eight-week supplementation of casein-derived tripeptides, VPP and IPP, ameliorated cen- tral blood pressure and arterial stiffness [81]. In a recent randomized, double-blind clinical trial, the administration of shrimp-derived peptides $(1200 \mathrm{mg} / \mathrm{d})$ for eight weeks reduced the $\mathrm{BP}$ in mild- or moderate-hypertension patients [79]. Additionally, the authors suggested that the reduction of BP was probably due to the decrease of angiotensin II levels in hypertension patients.

\section{The Role of Dietary Bioactive Peptides in Inflammatory Bowel Diseases (IBD)}

Inflammation is a complex and natural response of the body in an attempt to resolve harmful stimuli such as pathogens, tissue injuries, infections, or toxins. However, uncontrolled and chronic inflammation has been reported to be linked with several diseases such as T2DM, metabolic syndrome, IBD, cardiovascular disease, cancer, asthma, arthritis, and chronic obstructive lung disease [101]. IBD symptoms such as diarrhea, abdominal pain, fever, vomiting, BW loss, and rectal bleeding affect the quality of life of patients [102]. Crohn's disease (DC) and ulcerative colitis (UC) are two major forms of IBD [103]. UC is the inflammation of colon. Chronic inflammation in the intestine produces excessive and uncontrolled proinflammatory cytokines including tumor necrosis factor-alpha (TNF- $\alpha$ ), interleukin- (IL-) $1 \beta$, IL-6, IL-8, IL-12, interferon-gamma (IFN- $\gamma$ ), and IL-17 $[102,103]$.

The mechanism of anti-inflammation by food proteinderived BPs is that they can inhibit the phosphorylation of signaling pathways including nuclear factor-kappa B (NF$\kappa \mathrm{B})$, mitogen-activated protein kinase (MAPK), Janus kinase-signal transducer and activator of transcription (JAK-STAT), and peptide transporter PepT1 as shown in Figure $2[26,104,105]$. The NF- $\kappa$ B pathway contains IKKs, $\mathrm{I} \kappa \mathrm{Bs}$, and $\mathrm{p} 65 / \mathrm{p} 50$, while the MAPK pathway contains $\mathrm{p} 38$, JNK, and extracellular signal-regulated kinases (ERK). BPs can inhibit the NF- $\kappa \mathrm{B}$ receptor, resulting in the inhibition of the activation of inhibitory $\kappa \mathrm{B}$ kinases (IKK $\alpha / \beta / \gamma)$, which can lead to phosphorylation of cytoplasmic transcription factor $(\mathrm{I} \kappa \mathrm{B} \alpha / \beta / \gamma)$ and $\mathrm{I} \kappa \mathrm{B} \alpha$ degradation. BPs can inhibit the MAPK receptor and inhibit MAP3K phosphorylation, which can mediate the phosphorylation of the downstream MAP2K and MAPK. The inhibition of phosphorylation of MAPK and JAK2-STATs by BPs can alleviate the release of cytokines. The BP inhibition of translocations of the above transcription factors in nucleus (ATF-2, AP-1, and c-Jun) can cause the gene change, reducing the productions of proinflammatory cytokines, such as IL- $1 \beta$, IL- 6 , IL- 8 , TNF- $\alpha$, and IFN$\gamma$, resulting in the inflammation suppression (Figure 2). In addition, the PepT1 can transport small BPs to the bloodstream; therefore, the role of PepT1 is vital to the bioactivity of BPs and needs further investigation $[15,26]$.

Peptides isolated from a variety of dietary protein sources (e.g., soy bean, common bean, corn, egg white, whey, casein, salmon, and crucian carp) have shown to inhibit intestinal inflammation through multiple molecular mechanisms. These include downregulation of the expression of IL-8, IL$1 \beta$, IL- 6 , TNF- $\alpha$, IFN- $\gamma$, IL-12, and IL-17; upregulation of IL-10; and inhibition of activation of the NF- $\kappa$ B and MAPK 
TABLE 4: Molecular mechanisms of action of antihypertensive peptides isolated from various food sources.

\begin{tabular}{|c|c|c|c|c|c|c|}
\hline $\begin{array}{l}\text { Dietary protein } \\
\text { source }\end{array}$ & $\begin{array}{l}\text { Enzyme used to } \\
\text { produce } \\
\text { peptides }\end{array}$ & $\begin{array}{l}\text { Peptide sequence or } \\
\text { molecular weight }\end{array}$ & Object & $\begin{array}{l}\mathrm{IC}_{50} / \mathrm{EC}_{50} \\
\text { values }\end{array}$ & Activity/mechanisms of action & Reference \\
\hline Pea protein & Thermolysin & $<3 \mathrm{kDa}$ & $\begin{array}{l}\text { SHR and clinical } \\
\text { trial }\end{array}$ & - & $\begin{array}{l}\text { Peptides (100 and } 200 \mathrm{mg} / \mathrm{kg} \\
\text { BW) reduced SBP }\end{array}$ & {$[140]$} \\
\hline Casein & - & VPP and IPP & Clinical trial & - & $\begin{array}{c}\text { VPP and IPP improved central } \\
\text { blood pressure and arterial } \\
\text { stiffness }\end{array}$ & {$[81]$} \\
\hline $\begin{array}{l}\text { Pistachio } \\
\text { kernel }\end{array}$ & $\begin{array}{l}\text { Pepsin and } \\
\text { trypsin }\end{array}$ & ACKEP & $\begin{array}{l}\text { ACE inhibition } \\
\text { assay }\end{array}$ & $\begin{array}{c}\text { ACE IC } \\
126 \mu \mathrm{M}\end{array}$ & $\begin{array}{l}\text { ACKEP inhibited ACE by } \\
\text { binding with ACE active site }\end{array}$ & {$[88]$} \\
\hline $\begin{array}{l}\text { Chum salmon } \\
\text { (Oncorhynchus } \\
\text { keta) skin }\end{array}$ & Trypsin & GLPLNLP & $\begin{array}{l}\text { ACE inhibition } \\
\text { assay and SHRs }\end{array}$ & $\begin{array}{l}{\mathrm{ACE} \mathrm{IC}_{50}}_{18.7 \mu \mathrm{M}}\end{array}$ & $\begin{array}{c}\text { GLP exhibited ACE inhibition } \\
\text { and antihypertensive effect by } \\
\text { decreasing SBP }\end{array}$ & {$[94]$} \\
\hline $\begin{array}{l}\text { Skate } \\
\text { (Okamejei } \\
\text { kenojei) skin }\end{array}$ & $\begin{array}{l}\text { Alcalase and } \\
\text { protease }\end{array}$ & $\begin{array}{l}\text { LGPLGHQ and } \\
\text { MVGSAPGVL }\end{array}$ & $\begin{array}{l}\text { ACE inhibition } \\
\text { assay and SHRs }\end{array}$ & $\begin{array}{l}\mathrm{ACE} \mathrm{IC}_{50} \\
3.09-4.22 \\
\mu \mathrm{M}\end{array}$ & $\begin{array}{l}\text { Peptides inhibited ACE and } \\
\text { decreased SBP and inhibited } \\
\text { vasoconstriction via PPAR- } \gamma \\
\text { expression, activation, and } \\
\text { phosphorylation of eNOS in } \\
\text { lungs }\end{array}$ & {$[95]$} \\
\hline $\begin{array}{l}\text { Egg white } \\
\text { ovotransferrin }\end{array}$ & $\begin{array}{l}\text { Thermolysin } \\
\text { and pepsin }\end{array}$ & IQW and LKP & SHRs & - & $\begin{array}{l}\text { Peptides reduced mean blood } \\
\text { pressure }\end{array}$ & {$[22]$} \\
\hline $\begin{array}{l}\text { Cuttlefish } \\
\text { (Sepia } \\
\text { officinalis) } \\
\text { muscle }\end{array}$ & $\begin{array}{l}\text { Crude enzymes } \\
\text { from } B \text {. } \\
\text { mojavensis and } \\
\text { cuttle fish } \\
\text { hepatopancreas }\end{array}$ & $\begin{array}{l}\text { VELYP, AFVGYVLP, } \\
\text { and EKSYELP }\end{array}$ & $\begin{array}{l}\text { ACE inhibition } \\
\text { assay and SHRs }\end{array}$ & $\begin{array}{l}\mathrm{ACE} \mathrm{IC}_{50} \\
5.22 \mu \mathrm{M}\end{array}$ & $\begin{array}{l}\text { VELYP showed strong ACE } \\
\text { inhibition through a } \\
\text { noncompetitive inhibition and } \\
\text { had antihypertensive effects by } \\
\text { decreasing SBP }\end{array}$ & [96] \\
\hline $\begin{array}{l}\text { Potato and } \\
\text { rapeseed }\end{array}$ & $\begin{array}{l}\text { Alcalase and } \\
\text { potato autolysis }\end{array}$ & $\begin{array}{l}\text { SLVSPSAAAAAAPGGS } \\
\text { and KKRSKKKSFG }\end{array}$ & $\begin{array}{l}\text { Goldblatt rat } \\
\text { with } \\
\text { hypertension } \\
\text { and ACE } \\
\text { inhibition }\end{array}$ & $\begin{array}{l}\mathrm{ACE} \mathrm{IC}_{50} \\
324 \\
\mu \mathrm{g} / \mathrm{mL} \\
\text { and } 156 \\
\mu \mathrm{g} / \mathrm{mL}\end{array}$ & $\begin{array}{c}\text { Peptides inhibited ACE and } \\
\text { exhibited antihypertensive effects } \\
\text { by reducing SBP }\end{array}$ & {$[85]$} \\
\hline $\begin{array}{l}\text { Rice bran } \\
\text { protein }\end{array}$ & Trypsin & YSK & $\begin{array}{l}\text { ACE inhibition } \\
\text { assay }\end{array}$ & $\begin{array}{l}\mathrm{ACE} \mathrm{IC}_{50} \\
76 \mathrm{mM}\end{array}$ & $\begin{array}{l}\text { YSK showed ACE inhibition } \\
\text { through the formation of } \\
\text { hydrogen bonds with active } \\
\text { pockets of human ACE }\end{array}$ & {$[1]$} \\
\hline $\begin{array}{l}\text { Sipuncula } \\
\text { (Phascolosoma } \\
\text { esculenta) }\end{array}$ & $\begin{array}{l}\text { Pepsin and } \\
\text { trypsin }\end{array}$ & $\begin{array}{l}\text { RYDF, YASGR and } \\
\text { GNGSGYVSR }\end{array}$ & $\begin{array}{l}\text { ACE inhibition } \\
\text { assay and SHRs }\end{array}$ & $\begin{array}{l}\mathrm{ACE} \mathrm{IC}_{50} \\
235 \mu \mathrm{M} \\
185 \mu \mathrm{M} \\
\text { and } 29 \\
\mu \mathrm{M}\end{array}$ & $\begin{array}{c}\text { Three peptides inhibited ACE } \\
\text { noncompetitively. GNGSGYVSR } \\
(5 \mathrm{mg} / \mathrm{kg} \mathrm{BW}) \text { showed } \\
\text { antihypertensive effect by } \\
\text { decreasing SBP }\end{array}$ & {$[97]$} \\
\hline $\begin{array}{l}\text { Lentil seeds } \\
\text { (Lens culinaris } \\
\text { var.) }\end{array}$ & Savinase & $\begin{array}{l}\text { LLSGTQNQPSFLSGF, } \\
\text { NSLTLPILRYL, and } \\
\text { TLEPNSVFLPVLLH }\end{array}$ & $\begin{array}{l}\text { ACE inhibition } \\
\text { assay }\end{array}$ & $\begin{array}{c}\mathrm{ACE} \mathrm{IC}_{50} \\
44-120 \\
\mu \mathrm{M}\end{array}$ & $\begin{array}{l}\text { Inhibited ACE through } \\
\text { interaction by hydrogen bonds } \\
\text { with three ACE residues of the } \\
\text { catalytic site }\end{array}$ & [91] \\
\hline $\begin{array}{l}\text { Bighead carp } \\
\text { muscle }\end{array}$ & Pepsin & $\begin{array}{l}\text { YNLKERYAAW and } \\
\text { YNRLPEL }\end{array}$ & $\begin{array}{l}\text { ACE inhibition } \\
\text { assay }\end{array}$ & $\begin{array}{c}\mathrm{ACE} \mathrm{IC}_{50} \\
1.35-3.42 \\
\mu \mathrm{M}\end{array}$ & Peptides inhibited ACE activity & [98] \\
\hline Bovine casein & $\begin{array}{l}\text { Pepsin and } \\
\text { trypsin }\end{array}$ & YQKFPQYLQY & $\begin{array}{l}\text { ACE inhibition } \\
\text { assay and SHRs }\end{array}$ & $\begin{array}{c}\mathrm{ACE} \mathrm{IC}_{50} \\
11.1 \mu \mathrm{M}\end{array}$ & $\begin{array}{c}\text { Peptide inhibited ACE via } \\
\text { competitive inhibition and } \\
\text { exhibited antihypertension by } \\
\text { decreasing SBP }\end{array}$ & {$[82]$} \\
\hline \multirow[t]{2}{*}{$\begin{array}{l}\text { Hazelnut } \\
\text { (Corylus } \\
\text { heterophylla } \\
\text { Fisch.) }\end{array}$} & Alcalase & $\begin{array}{l}\text { AVKVL, YLVR, and } \\
\text { TLVGR }\end{array}$ & $\begin{array}{l}\text { ACE inhibition } \\
\text { assay and SHRs }\end{array}$ & $\begin{array}{l}\mathrm{ACE} \mathrm{IC}_{50} \\
15.42- \\
249.3 \mu \mathrm{M}\end{array}$ & $\begin{array}{l}\text { Peptides inhibited ACE activity } \\
\text { via a noncompetitive mode via } \\
\text { the formation of cation-pi } \\
\text { interactions and YLVR reduced } \\
\text { SBP }\end{array}$ & [89] \\
\hline & & YV & & & & [93] \\
\hline
\end{tabular}


TABLE 4: Continued.

\begin{tabular}{|c|c|c|c|c|c|c|}
\hline $\begin{array}{l}\text { Dietary protein } \\
\text { source }\end{array}$ & $\begin{array}{l}\text { Enzyme used to } \\
\text { produce } \\
\text { peptides }\end{array}$ & $\begin{array}{l}\text { Peptide sequence or } \\
\text { molecular weight }\end{array}$ & Object & $\begin{array}{l}\mathrm{IC}_{50} / \mathrm{EC}_{50} \\
\text { values }\end{array}$ & Activity/mechanisms of action & Reference \\
\hline $\begin{array}{l}\text { Egg white from } \\
\text { ostrich }\end{array}$ & $\begin{array}{l}\text { Alkaline } \\
\text { hydrolysis }\end{array}$ & & $\begin{array}{l}\text { ACE inhibition } \\
\text { assay }\end{array}$ & $\begin{array}{l}\mathrm{ACE} \mathrm{IC}_{50} \\
63.97 \\
\mu \mathrm{g} / \mathrm{mL}\end{array}$ & $\begin{array}{l}\text { YV showed ACE inhibition by } \\
\text { binding to S1 and S2 ACE pocket } \\
\text { sites via hydrogen bonds }\end{array}$ & \\
\hline Soybean & $\begin{array}{l}\text { Pediococcus } \\
\text { pentosaceus } \\
\text { SDL1409 }\end{array}$ & $\begin{array}{l}\text { EDEVSFSP, SRPFNL, } \\
\text { RSPFNL, and ENPFNL }\end{array}$ & $\begin{array}{l}\text { ACE inhibition } \\
\text { assay }\end{array}$ & $\begin{array}{c}\mathrm{ACE} \mathrm{IC}_{50} \\
0.131- \\
0.811 \\
\mathrm{mg} / \mathrm{mL}\end{array}$ & $\begin{array}{l}\text { Peptides inhibited ACE via } \\
\text { essential N-terminal sequence } \\
\text { and amino acid position }\end{array}$ & {$[84]$} \\
\hline $\begin{array}{l}\text { Shrimp } \\
\text { (Pandalus } \\
\text { borealis) } \\
\text { protein }\end{array}$ & - & - & $\begin{array}{l}\text { Randomized, } \\
\text { double-blind, } \\
\text { placebo- } \\
\text { controlled, 8- } \\
\text { week clinical } \\
\text { study }\end{array}$ & - & $\begin{array}{l}\text { Peptides }(1200 \mathrm{mg} / \mathrm{d}) \text { reduced the } \\
\text { blood pressure due to a reduction } \\
\text { of angiotensin II levels }\end{array}$ & [79] \\
\hline $\begin{array}{l}\text { Beef (Bos } \\
\text { taurus } \\
\text { coreanae) } \\
\text { myofibrillar } \\
\text { proteins }\end{array}$ & $\begin{array}{l}\text { Alkaline-AK } \\
\text { and papain }\end{array}$ & LIVGIIRCV & $\begin{array}{l}\text { ACE inhibition } \\
\text { assay and SHRs }\end{array}$ & - & $\begin{array}{c}\text { Peptides ( } 400 \text { and } 800 \mathrm{mg} / \mathrm{kg} \\
\text { BW) inhibited ACE by } 74.29 \% \\
\text { and decreased SBP }\end{array}$ & [99] \\
\hline Milk & $\begin{array}{l}\text { Fermented } \\
\text { using L. } \\
\text { delbrueckii } \\
\text { QS306 }\end{array}$ & LPYPY & $\begin{array}{l}\text { ACE inhibition } \\
\text { assay }\end{array}$ & $\begin{array}{c}\mathrm{ACE} \mathrm{IC}_{50} \\
12.87 \\
\mu \mathrm{g} / \mathrm{mL}\end{array}$ & $\begin{array}{l}\text { LPYPY inhibited ACE with } \mathrm{IC}_{50} \\
\qquad 12.87 \mu \mathrm{g} / \mathrm{mL}\end{array}$ & {$[80]$} \\
\hline $\begin{array}{l}\text { Mung bean } \\
\text { protein }\end{array}$ & Bromelain & $\begin{array}{l}\text { LPRL, YADLVE, } \\
\text { LRLESF, HLNVVHEN, } \\
\text { and PGSGCAGTDL }\end{array}$ & $\begin{array}{l}\text { ACE inhibition } \\
\text { assay and SHRs }\end{array}$ & $\begin{array}{l}\mathrm{ACE} \mathrm{IC}_{50} \\
5.39- \\
1912 \mu \mathrm{M}\end{array}$ & $\begin{array}{l}\text { Peptides showed ACE inhibition } \\
\text { and reduced SBP }\end{array}$ & {$[90]$} \\
\hline $\begin{array}{l}\text { Seahorse } \\
\text { (Hippocampus } \\
\text { abdominalis) }\end{array}$ & Protamex & $\begin{array}{l}\text { APTL, CNVPLSP, and } \\
\text { PWTPL }\end{array}$ & $\begin{array}{l}\text { ACE inhibition } \\
\text { assay and SHRs }\end{array}$ & $\begin{array}{l}\mathrm{ACE} \mathrm{IC}_{50} \\
0.044 \mu \mathrm{M}\end{array}$ & $\begin{array}{l}\text { Peptides exhibited } \\
\text { antihypertension by lowering } \\
\text { blood pressure via vasodilation } \\
\text { and ACE inhibition }\end{array}$ & {$[92]$} \\
\hline $\begin{array}{l}\text { Black cumin } \\
\text { seed }\end{array}$ & $\begin{array}{c}\alpha- \\
\text { Chymotrypsin }\end{array}$ & VTPVGVPK & $\begin{array}{l}\text { ACE inhibition } \\
\text { assay }\end{array}$ & $\begin{array}{c}\mathrm{ACE} \mathrm{IC}_{50} \\
\text { value } 1.8 \\
\mu \mathrm{M}\end{array}$ & $\begin{array}{l}\text { VTPVGVPK inhibited ACE via a } \\
\text { noncompetitive inhibition }\end{array}$ & {$[86]$} \\
\hline Quinoa protein & Chymotrypsin & QHPHGLGALCAAPPST & $\begin{array}{l}\text { ACE inhibition } \\
\text { assay }\end{array}$ & - & $\begin{array}{l}\text { Peptide displayed ACE inhibition } \\
\text { by binding to ACE active hotspots }\end{array}$ & {$[62]$} \\
\hline $\begin{array}{l}\text { White } \\
\text { turmeric, } \\
\text { turmeric, and } \\
\text { ginger proteins }\end{array}$ & $\begin{array}{l}\text { Pepsin and } \\
\text { trypsin }\end{array}$ & $\begin{array}{l}\text { VTYM, RGPFH, AEPPR, } \\
\text { GSGLVP, KM, SPV, } \\
\text { CACGGV, DVDP, } \\
\text { CGVGAA, HVVV, and } \\
\text { RSC }\end{array}$ & $\begin{array}{l}\text { ACE inhibition } \\
\text { assay }\end{array}$ & $\begin{array}{l}\mathrm{ACE} \mathrm{IC}_{50} \\
16.4-36.5 \\
\mu \mathrm{M}\end{array}$ & Peptides showed ACE inhibition & {$[9]$} \\
\hline Coix prolamin & Pepsin & VDMF & $\begin{array}{l}\text { ACE inhibition } \\
\text { assay }\end{array}$ & $\begin{array}{l}\mathrm{ACE} \mathrm{IC}_{50} \\
382.28 \mu \mathrm{M}\end{array}$ & $\begin{array}{c}\text { VDMF reduced ACE and AT1R } \\
\text { expression in AngII-injury } \\
\text { HUVECs }\end{array}$ & {$[87]$} \\
\hline Wheat gluten & $\begin{array}{l}\text { Alcalase and } \\
\text { PaproA }\end{array}$ & $\begin{array}{l}\text { SAGGYIW and } \\
\text { APATPSFW }\end{array}$ & $\begin{array}{c}\text { ACE inhibition } \\
\text { assay }\end{array}$ & $\begin{array}{l}\mathrm{ACE} \mathrm{IC}_{50} \\
0.002- \\
0.036 \\
\mathrm{mg} / \mathrm{mL}\end{array}$ & $\begin{array}{l}\text { Peptides and negatively charged } \\
\text { amino acids inhibited ACE via } \\
\text { modulating ionic and } \\
\text { hydrophobic interactions on ACE } \\
\text { catalytic sites }\end{array}$ & {$[83]$} \\
\hline
\end{tabular}

ACE: angiotensin-converting enzyme; BW: body weight; $\mathrm{IC}_{50}$ : 50\% inhibitory concentration; SBP: systolic blood pressure; SHR: spontaneously hypertensive rat; PPAR- $\gamma$ : peroxisome proliferator-activated receptor $\gamma$.

pathways via suppression of phosphorylation of p65, ERK1/2, p38, JNK1/2, and Syk signaling molecules [102, $103,106,107]$. The isolated peptides and their molecular mechanisms of anti-intestinal inflammatory effects are presented in Table 5.
Dietary anti-intestinal inflammatory peptides are short chains of AAs that generally contain 2-10 AAs. The common AAs of these peptides are alanine, valine, leucine, serine, methionine, tyrosine, and phenylalanine [102, 103, 108]. Pepsin and pancreatin are the two most commonly employed 


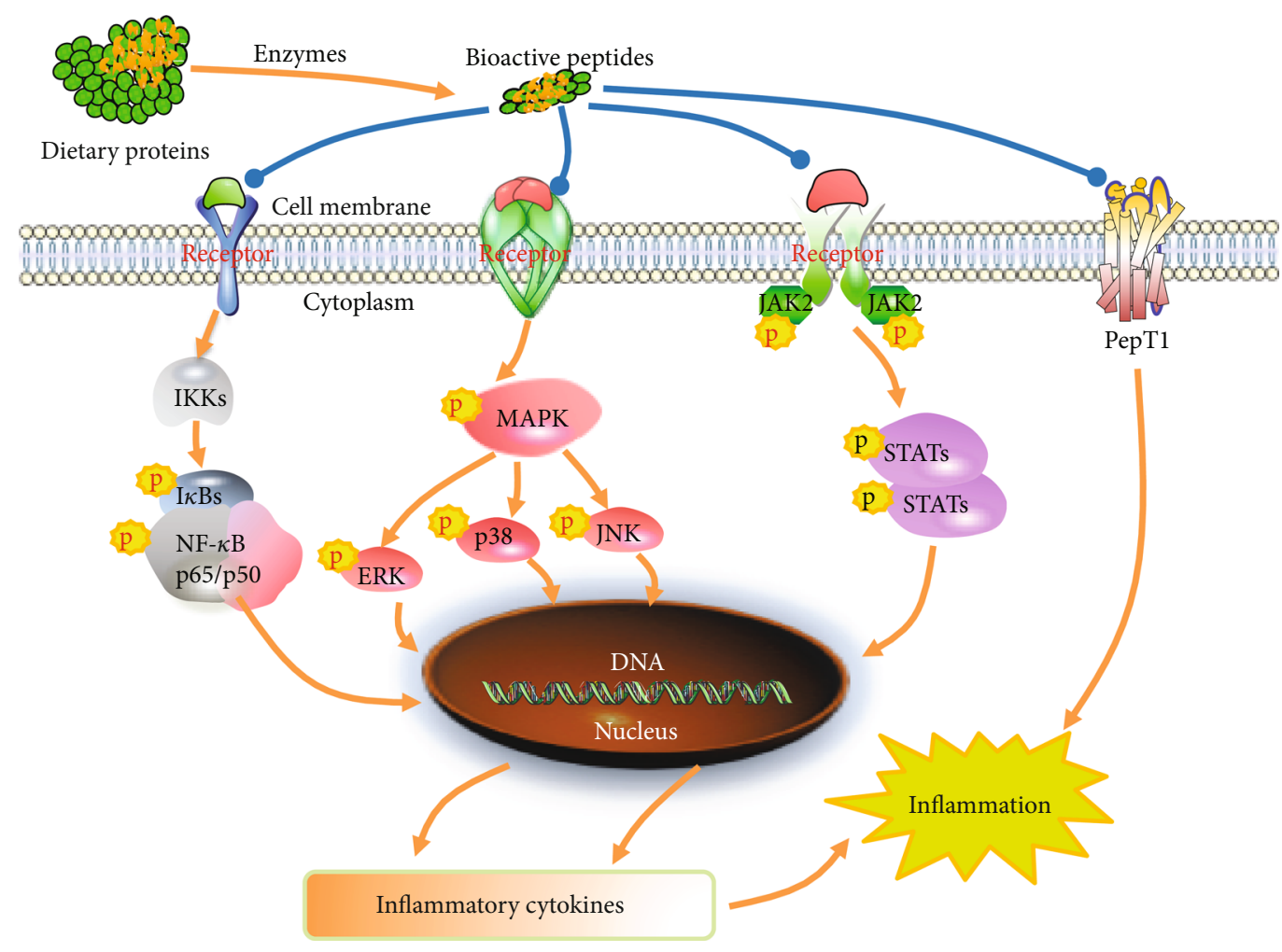

FIGURE 2: The mechanism of anti-inflammation of dietary protein-derived bioactive peptides: NF- $\kappa$ B, MAPK, JAK2-STAT, and PepT1. ERK: extracellular signal-regulated kinases; MAPK: mitogen-activated protein kinase; NF- $\kappa$ B: nuclear factor-kappa B; JAK-STAT: Janus kinasesignal transducer and activator of transcription; JNK: c-Jun N-terminal kinase; p: phosphorylation; PepT1: peptide transport 1.

proteolytic enzymes to produce anti-inflammatory peptides from various food proteins $[103,109,110]$. The TNF- $\alpha-$ treated Caco- 2 cell is a widely used human intestinal cell model for the investigation of the anti-inflammatory property of dietary peptides. TNF- $\alpha$ activates the both NF- $\kappa \mathrm{B}$ and MAPK signaling pathways in Caco- 2 cells and thereby produces large quantities of proinflammatory mediators [110]. Excess and uncontrolled production of proinflammatory cytokines plays a vital role in the progression of intestinal inflammation [103].

Numerous recent studies reported that dietary BPs could inhibit the intestinal inflammation through the reduction of proinflammatory mediators. Four peptides, DEDTQAMPFR, MLGATSL, SLSFASR, and MSYSAGF, isolated from egg white exerted anti-inflammatory activities in colitis mouse by inhibiting the production of TNF- $\alpha$ and IL- 6 as well as reducing the mRNA-expressions TNF- $\alpha$, IL-6, IL17, IL-1 $\beta$, IFN- $\gamma$, and MCP-1 [111]. Tripeptide VPY from soybean inhibited IL- 8 secretion in Caco- 2 cells [108]. The peptide was also found to decrease the mRNA expressions of inflammatory mediators TNF- $\alpha$, IL- 6, IL- $1 \beta$, IFN- $\gamma$, and IL-17 in the peptide-treated mice colon. Dipeptides (CR, $\mathrm{FL}, \mathrm{HC}, \mathrm{LL}$, and MK) produced from egg white ovotransferrin, by using pepsin and trypsin hydrolysis, decreased the gene expression of TNF- $\alpha$, IL- 8 , IL- 6 , IL- $1 \beta$, and IL-12, while enhancing IL-10 expression, in Caco-2 cells [103]. Crucian carp-derived 178 peptides $(<1500 \mathrm{Da})$ at 50,100 , and 150 $\mu \mathrm{g} / \mathrm{mL}$ considerably reduced the secretion of TNF- $\alpha$, IL- 6 , and IL- $1 \beta$ in IEC- 6 small intestine cells as well as in dextran sodium sulfate-induced ulcerative colitis mice [106].

Several recent reports demonstrated the role of $\mathrm{NF}-\kappa \mathrm{B}$ in the pathogenesis of IBD [106]. Activation of NF- $\kappa \mathrm{B}$ has been shown to be involved in the IBD patients [112]. The NF- $\kappa$ B and MAPK pathways are two vital proinflammatory signaling pathways that majorly regulate cellular inflammatory responses by secreting various cytokines after activation by various inflammatory stimuli [113]. Transcription factor $\mathrm{NF}-\kappa \mathrm{B}$ regulates the inflammatory responses by stimulating the production of various proinflammatory cytokines and chemokines. Phosphorylation of $\mathrm{I} \kappa \mathrm{B}$ by inflammatory stimuli (LPS and TNF- $\alpha$ ) releases the NF- $\kappa \mathrm{B}$ that migrates to the nucleus and activates expression of the numerous genes connected with inflammation $[110,112]$. The MAPK family contains three components such as p38 MAPK, ERK1/2, and JNK/SAPK. Phosphorylation of MAPK components stimulates the other kinases and migrates to the nucleus where they induce the transcription of several inflammatory genes and thereby enhance the secretion of proinflammatory mediators [110].

Peptides derived from egg, milk, fish, and beans exhibited the anti-intestinal inflammatory activity through the inhibition of MAPK and NF- $\kappa$ B molecular pathways [102, 103, 110]. A tetrapeptide, IPAV, isolated from whey proteins exhibited anti-inflammatory activity in Caco- 2 cells by inhibiting IL-8 expression and by suppression of phosphorylation of p65, ERK1/2, p38, JNK1/2, and Syk signaling 


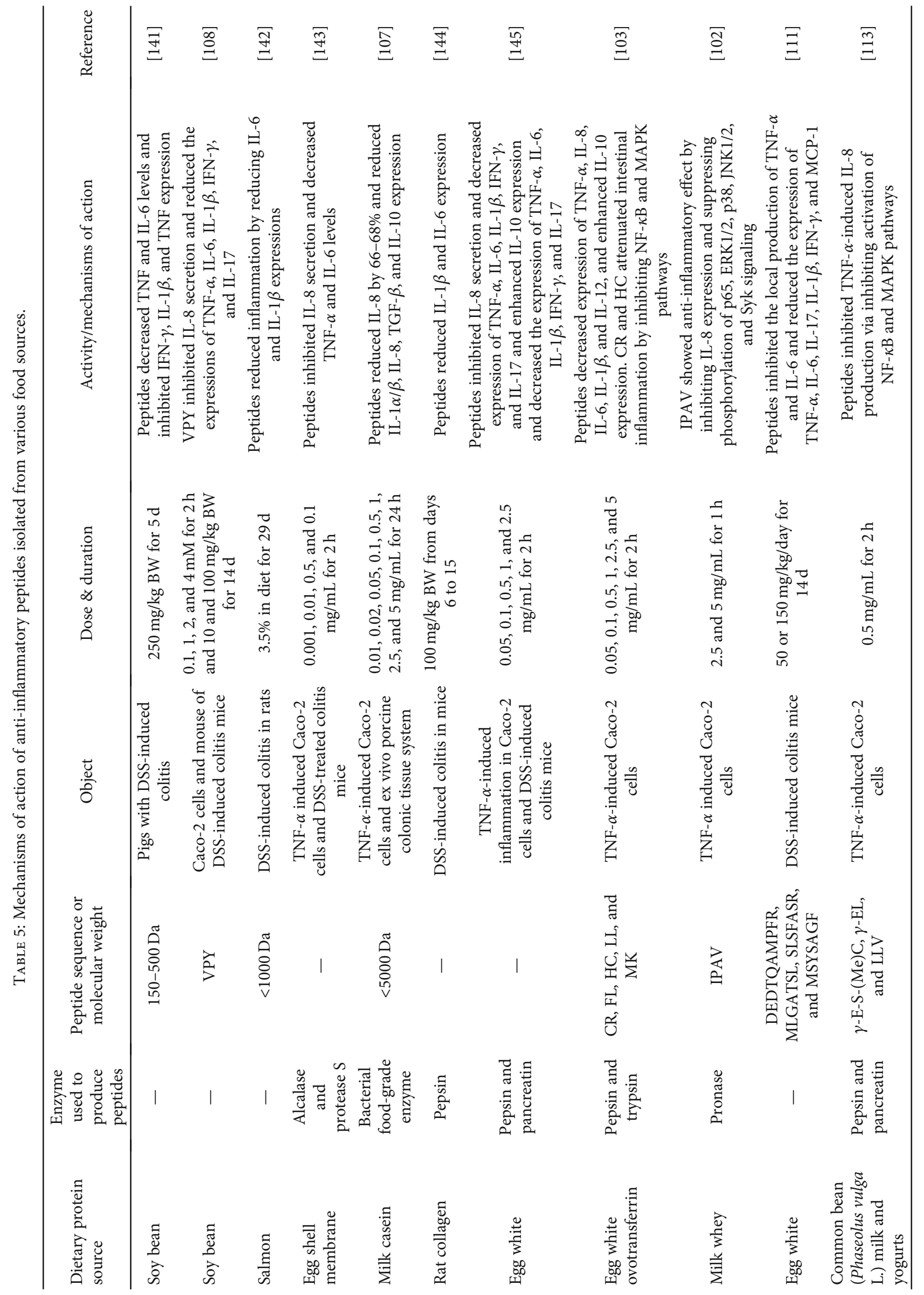




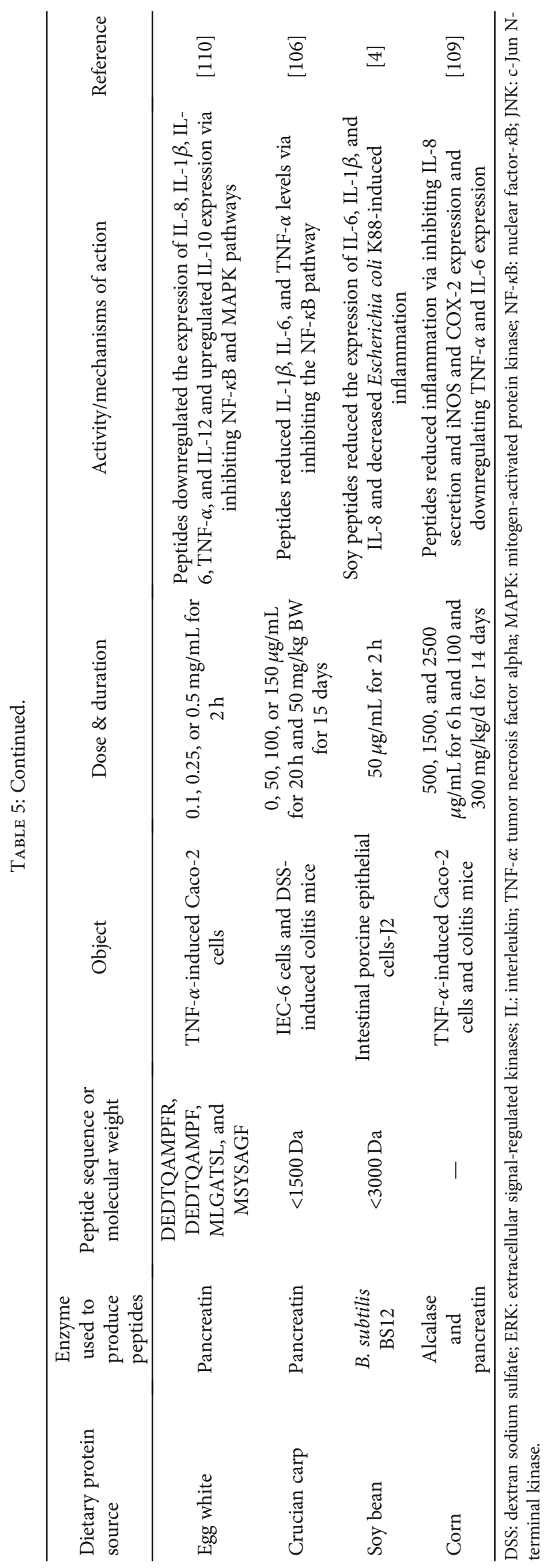


molecules [102]. Bean milk- and yogurt-derived LLV, $\gamma$-E-S$(\mathrm{Me}) \mathrm{C}$, and $\gamma$-EL inhibited TNF- $\alpha$-induced IL- 8 production and gene expression of inflammatory mediators, TNF- $\alpha$, IL-1 $\beta$, IL-8, and IL- 6 , through the inhibition of phosphorylation of I $\kappa$ B- $\alpha$ of NF- $\kappa$ B and JNK of MAPK signaling pathways in Caco-2 cells [113]. Four peptides DEDTQAMPFR, DEDTQAMPF, MLGATSL, and MSYSAGF isolated from egg considerably suppressed the phosphorylation of JNK, p38, and I $\kappa$ B of NF- $\kappa$ B and MAPK signaling pathways and thereby reduced the gene expression of IL-8, IL-1 $\beta$, IL-6, TNF- $\alpha$, and IL-12 in TNF- $\alpha$-stimulated Caco- 2 cells [110]. These results indicated that dietary BPs had the potential to treat inflammation or IBD via NF- $\kappa$ B or MAPK or other signaling pathways.

\section{Conclusions and Further Perspectives}

Numerous dietary peptides showed beneficial effects on redox balance and metabolic disorders (obesity, T2D, hypertension, and inflammation). Dietary peptides modulated several molecular mechanisms (e.g., Keap1-Nrf2-ARE signaling pathway in oxidative stress, PPAR- $\gamma$, C/EBP- $\alpha$, SREBP1 pathway in obesity, IRS-1/PI3K/Akt and AMPK signaling pathways in T2D, ACE inhibition in hypertension, and MAPK in IBD) and thereby exerted positive effects in redox balance and metabolic disorders. Most of the studies are conducted using cell and animal models. Although substantial evidence from cell and animal investigations is available for the BPs as described in this review, scientific evidence from clinical studies is still meager. Hence, more clinical investigations are needed to get in-depth knowledge about the BP's efficacy, absorption, distribution, metabolism, excretion, toxicity, and effect on gut microbiome in the human body in the future. In the future, the benefits and risks of longterm and large-quantity consumption of BPs on human health need to be addressed. The interaction of BPs with other drugs in the human body has to be investigated comprehensively. Additionally, newer technologies are needed to produce BPs cost effectively from dietary sources. The BPs should be produced with consumer-acceptable taste, quality, and stability. Although there are several challenges for future growth, the dietary BPs could be used as health foods in the management/prevention of metabolic disorders (obesity, T2DM, hypertension, and inflammation) and oxidative stress-related diseases (e.g., cancer and IBD). We hope that the BP's industry will have a bright future in the coming years as people are increasingly aware of health benefits of dietary BPs.

\section{Data Availability}

No data were used to support this review article.

\section{Conflicts of Interest}

The authors declare no conflict of interest.

\section{Authors' Contributions}

Qinqin Qiao, Liang Chen, Xiang Li, Xiangyang Lu, and Qingbiao $\mathrm{Xu}$ wrote the manuscript. Xiang $\mathrm{Li}$, Xiangyang $\mathrm{Lu}$, and Qingbiao $\mathrm{Xu}$ revised the manuscript. All authors reviewed and approved the final manuscript. Qinqin Qiao, Liang Chen, and Xiang Li contributed equally to this work.

\section{Acknowledgments}

This work was supported by grants from the Open Project Program of Key Laboratory of Feed Biotechnology, the Fundamental Research Funds for the Central Universities (2662019QD021), the State Key Laboratory of Animal Nutrition (2004DA125184F1906), the National Natural Science Foundation of China (C31802087), and the Key Laboratory of Molecular Animal Nutrition of Zhejiang University.

\section{References}

[1] X. Wang, H. Chen, X. Fu, S. Li, and J. Wei, "A novel antioxidant and ACE inhibitory peptide from rice bran protein: biochemical characterization and molecular docking study," LWT, vol. 75, pp. 93-99, 2017.

[2] I. Jemil, O. Abdelhedi, R. Nasri et al., "Hypolipidemic, antiobesity and cardioprotective effects of sardinelle meat flour and its hydrolysates in high-fat and fructose diet fed Wistar rats," Life Sciences, vol. 176, pp. 54-66, 2017.

[3] J. Zhang, M. Li, G. Zhang et al., "Identification of novel antioxidant peptides from snakehead (Channa argus) soup generated during gastrointestinal digestion and insights into the anti- oxidation mechanisms," Food Chemistry, vol. 337, p. 127921, 2021.

[4] Y. Zhang, S. Chen, X. Zong et al., "Peptides derived from fermented soybean meal suppresses intestinal inflammation and enhances epithelial barrier function in piglets," Food and Agricultural Immunology, vol. 31, no. 1, pp. 120-135, 2020.

[5] A. Bougatef, R. Ravallec, N. Nedjar-Arroume, A. Barkia, D. Guillochon, and M. Nasri, "Evidence of in vivo satietogen effect and control of food intake of smooth hound (Mustelus mustelus) muscle protein hydrolysate in rats," Journal of Functional Foods, vol. 2, no. 1, pp. 10-16, 2010.

[6] S. Marthandam Asokan, T. Wang, W.-T. Su, and W.-T. Lin, "Antidiabetic effects of a short peptide of potato protein hydrolysate in STZ-induced diabetic mice," Nutrients, vol. 11, no. 4, p. 779, 2019.

[7] P.-X. Gong, B.-K. Wang, Y.-C. Wu, Q.-Y. Li, B.-W. Qin, and H.-J. Li, "Release of antidiabetic peptides from Stichopus japonicas by simulated gastrointestinal digestion," Food Chemistry, vol. 315, article 126273, 2020.

[8] X. Fan, Y. Cui, R. Zhang, and X. Zhang, "Purification and identification of anti-obesity peptides derived from Spirulina platensis," Journal of Functional Foods, vol. 47, pp. 350-360, 2018.

[9] K. Sompinit, S. Lersiripong, O. Reamtong, W. Pattarayingsakul, N. Patikarnmonthon, and W. Panbangred, "In vitro study on novel bioactive peptides with antioxidant and antihypertensive properties from edible rhizomes," LWT, vol. 134, article 110227, 2020.

[10] Y. Oh, C.-B. Ahn, and J.-Y. Je, "Low molecular weight blue mussel hydrolysates inhibit adipogenesis in mouse 
mesenchymal stem cells through upregulating $\mathrm{HO}-1 / \mathrm{Nrf} 2$ pathway," Food Research International, vol. 136, article 109603, 2020.

[11] M. Hajfathalian, S. Ghelichi, P. J. García-Moreno, A.-D. Moltke Sørensen, and C. Jacobsen, "Peptides: production, bioactivity, functionality, and applications," Critical Reviews in Food Science and Nutrition, vol. 58, no. 18, pp. 3097-3129, 2018.

[12] K. Wang, L. Han, H. Hong, J. Pan, H. Liu, and Y. Luo, "Purification and identification of novel antioxidant peptides from silver carp muscle hydrolysate after simulated gastrointestinal digestion and transepithelial transport," Food Chemistry, vol. 342, article 128275, 2021.

[13] J. Wang, M. Zhou, T. Wu, L. Fang, C. Liu, and W. Min, "Novel anti-obesity peptide (RLLPH) derived from hazelnut (Corylus heterophylla Fisch) protein hydrolysates inhibits adipogenesis in 3T3-L1 adipocytes by regulating adipogenic transcription factors and adenosine monophosphateactivated protein kinase (AMPK) activation," Journal of Bioscience and Bioengineering, vol. 129, no. 3, pp. 259-268, 2020.

[14] R. Jin, X. Teng, J. Shang, D. Wang, and N. Liu, "Identification of novel DPP-IV inhibitory peptides from Atlantic salmon (Salmo salar) skin," Food Research International, vol. 133, article 109161, 2020.

[15] Q. Xu, H. Hong, J. Wu, and X. Yan, "Bioavailability of bioactive peptides derived from food proteins across the intestinal epithelial membrane: a review," Trends in Food Science and Technology, vol. 86, pp. 399-411, 2019.

[16] Q. Xu, H. Fan, W. Yu, H. Hong, and J. Wu, "Transport study of egg-derived antihypertensive peptides (LKP and IQW) using Caco-2 and HT29 coculture monolayers," Journal of Agricultural and Food Chemistry, vol. 65, no. 34, pp. 7406-7414, 2017.

[17] Q. Xu, X. Yan, Y. Zhang, and J. Wu, "Current understanding of transport and bioavailability of bioactive peptides derived from dairy proteins: a review," International Journal of Food Science and Technology, vol. 54, no. 6, pp. 1930-1941, 2019.

[18] Q. Lin, Q. Xu, J. Bai, W. Wu, H. Hong, and J. Wu, "Transport of soybean protein-derived antihypertensive peptide LSW across Caco-2 monolayers," Journal of Functional Foods, vol. 39, pp. 96-102, 2017.

[19] M. Chalamaiah, S. Keskin Ulug, H. Hong, and J. Wu, "Regulatory requirements of bioactive peptides (protein hydrolysates) from food proteins," Journal of Functional Foods, vol. 58, pp. 123-129, 2019.

[20] F. Ursini, M. Maiorino, and H. J. Forman, "Redox homeostasis: the Golden mean of healthy living," Redox Biology, vol. 8, pp. 205-215, 2016.

[21] H. Gu, J. Gao, Q. Shen et al., "Dipeptidyl peptidase-IV inhibitory activity of millet protein peptides and the related mechanisms revealed by molecular docking," $L W T$, vol. 138, article 110587, 2021.

[22] K. Majumder, S. Chakrabarti, J. S. Morton et al., "Egg-derived ACE-inhibitory peptides IQW and LKP reduce blood pressure in spontaneously hypertensive rats," Journal of Functional Foods, vol. 13, pp. 50-60, 2015.

[23] M. Son and J. Wu, "Egg white hydrolysate and peptide reverse insulin resistance associated with tumor necrosis factor- $\alpha$ (TNF- $\alpha$ ) stimulated mitogen-activated protein kinase (MAPK) pathway in skeletal muscle cells," European Journal of Nutrition, vol. 58, no. 5, pp. 1961-1969, 2019.

[24] P. Mudgil, H. Kamal, G. C. Yuen, and S. Maqsood, "Characterization and identification of novel antidiabetic and anti- obesity peptides from camel milk protein hydrolysates," Food Chemistry, vol. 259, pp. 46-54, 2018.

[25] L. Liang, S. Cai, M. Gao et al., "Purification of antioxidant peptides of Moringa oleifera seeds and their protective effects on $\mathrm{H}_{2} \mathrm{O}_{2}$ oxidative damaged Chang liver cells," Journal of Functional Foods, vol. 64, article 103698, 2020.

[26] W. Zhu, L. Ren, L. Zhang, Q. Qiao, M. Z. Farooq, and $\mathrm{Q}$. $\mathrm{Xu}$, "The potential of food protein-derived bioactive peptides against chronic intestinal inflammation," Mediators of Inflammation, vol. 2020, Article ID 6817156, 15 pages, 2020.

[27] E. H. Sarsour, M. G. Kumar, L. Chaudhuri, A. L. Kalen, and P. C. Goswami, "Redox control of the cell cycle in health and disease," Antioxidants \& Redox Signaling, vol. 11, no. 12, pp. 2985-3011, 2009.

[28] A. Ayer, C. W. Gourlay, and I. W. Dawes, "Cellular redox homeostasis, reactive oxygen species and replicative ageing in Saccharomyces cerevisiae," FEMS Yeast Research, vol. 14, no. 1 , pp. 60-72, 2014

[29] R. Basria, S. M. N. Mydin, and S. I. Okekpa, "Reactive Oxygen Species, Cellular Redox Homeostasis and Cancer," in Homeostasis - An Integrated Vision, IntechOpen, 2019.

[30] B. Marengo, M. Nitti, A. L. Furfaro et al., "Redox homeostasis and cellular antioxidant systems: crucial players in cancer growth and therapy," Oxidative Medicine and Cellular Longevity, vol. 2016, Article ID 6235641, 16 pages, 2016.

[31] X. Jiang, Z. Cui, L. Wang, H. Xu, and Y. Zhang, "Production of bioactive peptides from corn gluten meal by solid-state fermentation with Bacillus subtilis MTCC5480 and evaluation of its antioxidant capacity in vivo," LWT, vol. 131, p. 109767, 2020.

[32] F. Tonolo, A. Folda, L. Cesaro et al., "Milk-derived bioactive peptides exhibit antioxidant activity through the Keap1Nrf2 signaling pathway," Journal of Functional Foods, vol. 64, article 103696, 2020.

[33] B. C.-K. Tsai, D. J.-Y. Hsieh, W.-T. Lin et al., "Functional potato bioactive peptide intensifies Nrf2-dependent antioxidant defense against renal damage in hypertensive rats," Food Research International, vol. 129, article 108862, 2020.

[34] X. Lu, L. Zhang, Q. Sun, G. Song, and J. Huang, "Extraction, identification and structure-activity relationship of antioxidant peptides from sesame (Sesamum indicum L.) protein hydrolysate," Food Research International, vol. 116, pp. 707-716, 2019.

[35] M. Chalamaiah, B. Dinesh kumar, R. Hemalatha, and T. Jyothirmayi, "Fish protein hydrolysates: proximate composition, amino acid composition, antioxidant activities and applications: a review," Food Chemistry, vol. 135, no. 4, pp. 3020-3038, 2012.

[36] W. Rungratanawanich, M. Memo, and D. Uberti, "Redox homeostasis and natural dietary compounds: focusing on antioxidants of rice (Oryza sativa L.)," Nutrients, vol. 10, no. 11, p. 1605, 2018.

[37] L. Zheng, H. Yu, H. Wei et al., "Antioxidative peptides of hydrolysate prepared from fish skin gelatin using ginger protease activate antioxidant response element-mediated gene transcription in IPEC-J2 cells," Journal of Functional Foods, vol. 51, pp. 104-112, 2018.

[38] I. P. S. Fernando, S. Y. Park, E. J. Han et al., "Isolation of an antioxidant peptide from krill protein hydrolysates as a novel agent with potential hepatoprotective effects," Journal of Functional Foods, vol. 67, article 103889, 2020. 
[39] C. Wen, J. Zhang, Y. Feng, Y. Duan, H. Ma, and H. Zhang, "Purification and identification of novel antioxidant peptides from watermelon seed protein hydrolysates and their cytoprotective effects on $\mathrm{H}_{2} \mathrm{O}_{2}$-induced oxidative stress," Food Chemistry, vol. 327, article 127059, 2020.

[40] K. Sowmya, M. I. Bhat, R. Bajaj, S. Kapila, and R. Kapila, "Antioxidative and anti-inflammatory potential with transepithelial transport of a buffalo casein-derived hexapeptide (YFYPQL)," Food Bioscience, vol. 28, pp. 151-163, 2019.

[41] S. Awad, M. I. El-Sayed, A. Wahba, A. El Attar, M. I. Yousef, and M. Zedan, "Antioxidant activity of milk protein hydrolysate in alloxan-induced diabetic rats," Journal of Dairy Science, vol. 99, no. 11, pp. 8499-8510, 2016.

[42] Q. Zhang, X. Tong, X. Sui et al., "Antioxidant activity and protective effects of alcalase-hydrolyzed soybean hydrolysate in human intestinal epithelial Caco-2 cells," Food Research International, vol. 111, pp. 256-264, 2018.

[43] D. Ren, C. Liu, W. Liu et al., "Antifatigue, antioxidant and immunoregulatory effects of peptides hydrolyzed from Manchurian walnut (Juglans mandshurica Maxim.) on mice," Grain \& Oil Science and Technology, vol. 1, no. 1, pp. 44-52, 2018.

[44] Z. Zhang, G. Su, F. Zhou, L. Lin, X. Liu, and M. Zhao, “Alcalase-hydrolyzed oyster (Crassostrea rivularis) meat enhances antioxidant and aphrodisiac activities in normal male mice," Food Research International, vol. 120, pp. 178-187, 2019.

[45] N. Wang, W. Wang, F. A. Sadiq, S. Wang, L. Caiqin, and J. Jianchang, "Involvement of Nrf2 and Keap1 in the activation of antioxidant responsive element (ARE) by chemopreventive agent peptides from soft-shelled turtle," Process Biochemistry, vol. 92, pp. 174-181, 2020.

[46] Z. Zhang, S. Jiang, Y. Zeng, K. He, Y. Luo, and F. Yu, “Antioxidant peptides from Mytilus Coruscus on $\mathrm{H}_{2} \mathrm{O}_{2}$-induced human umbilical vein endothelial cell stress," Food Bioscience, vol. 38, p. 100762, 2020.

[47] M. Blüher, "Obesity: global epidemiology and pathogenesis," Nature Reviews Endocrinology, vol. 15, no. 5, pp. 288-298, 2019.

[48] R. Ruiz, R. Olías, A. Clemente, and L. A. Rubio, “A pea (Pisum sativum L.) seed vicilins hydrolysate exhibits PPAR $\gamma$ ligand activity and modulates adipocyte differentiation in a 3T3-L1 cell culture model," Foods, vol. 9, no. 6, p. 793, 2020.

[49] I. Kyrou, H. S. Randeva, C. Tsigos, G. Kaltsas, and M. O. Weickert, Clinical problems caused by obesity, Endotext, 2000.

[50] M. Desai, M. Beall, and M. G. Ross, "Developmental origins of obesity: programmed adipogenesis," Current Diabetes Reports, vol. 13, no. 1, pp. 27-33, 2013.

[51] J.-H. Hyung, C.-B. Ahn, and J.-Y. Je, "Ark shell protein hydrolysates inhibit adipogenesis in mouse mesenchymal stem cells through the down-regulation of transcriptional factors," RSC Advances, vol. 7, no. 11, pp. 6223-6228, 2017.

[52] M.-J. Tsou, F.-J. Kao, H.-C. Lu, H.-C. Kao, and W.D. Chiang, "Purification and identification of lipolysisstimulating peptides derived from enzymatic hydrolysis of soy protein," Food Chemistry, vol. 138, no. 2-3, pp. 14541460, 2013.

[53] M. E. Oseguera Toledo, E. Gonzalez de Mejia, M. Sivaguru, and S. L. Amaya-Llano, "Common bean (Phaseolus vulgaris L.) protein-derived peptides increased insulin secretion, inhibited lipid accumulation, increased glucose uptake and reduced the phosphatase and tensin homologue activation in vitro," Journal of Functional Foods, vol. 27, pp. 160-177, 2016.

[54] A. M. Alashi, C. L. Blanchard, R. J. Mailer et al., "Effects of canola proteins and hydrolysates on adipogenic differentiation of C3H10T/2 mesenchymal stem cells," Food Chemistry, vol. 185, pp. 226-232, 2015.

[55] E. J. Lee, J. Hur, S. A. Ham et al., "Fish collagen peptide inhibits the adipogenic differentiation of preadipocytes and ameliorates obesity in high fat diet-fed mice," International Journal of Biological Macromolecules, vol. 104, Part A, pp. 281-286, 2017.

[56] T. Mizushige, M. Komiya, M. Onda, K. Uchida, K. Hayamizu, and Y. Kabuyama, "Fish protein hydrolysate exhibits antiobesity activity and reduces hypothalamic neuropeptide Y and agouti-related protein mRNA expressions in rats," Biomedical Research, vol. 38, no. 6, pp. 351-357, 2017.

[57] B. Zhao, Y. Cui, X. Fan et al., "Anti-obesity effects of Spirulina platensis protein hydrolysate by modulating brain-liver axis in high-fat diet fed mice," PLoS One, vol. 14, no. 6, article e0218543, 2019.

[58] S. Wang, Z. Lv, W. Zhao, L. Wang, and N. He, "Collagen peptide from walleye pollock skin attenuated obesity and modulated gut microbiota in high-fat diet-fed mice," Journal of Functional Foods, vol. 74, article 104194, 2020.

[59] B. Framroze, S. Vekariya, and D. Swaroop, "A placebo-controlled, randomized study on the impact of dietary salmon protein hydrolysate supplementation on body mass index in overweight human subjects," Journal of Obesity and Weight Loss Therapy, vol. 6, no. 1, p. 296, 2016.

[60] T. M. Schnurr, H. Jakupović, G. D. Carrasquilla et al., "Obesity, unfavourable lifestyle and genetic risk of type 2 diabetes: a case-cohort study," Diabetologia, vol. 63, no. 7, pp. 13241332, 2020.

[61] A. Karimi, M. H. Azizi, and H. Ahmadi Gavlighi, "Fractionation of hydrolysate from corn germ protein by ultrafiltration: in vitro antidiabetic and antioxidant activity," Food Science \& Nutrition, vol. 8, no. 5, pp. 2395-2405, 2020.

[62] P. Mudgil, B. P. Kilari, H. Kamal et al., "Multifunctional bioactive peptides derived from quinoa protein hydrolysates: inhibition of $\alpha$-glucosidase, dipeptidyl peptidase-IV and angiotensin I converting enzymes," Journal of Cereal Science, vol. 96, article 103130, 2020.

[63] R. Wang, H. Zhao, X. Pan, C. Orfila, W. Lu, and Y. Ma, "Preparation of bioactive peptides with antidiabetic, antihypertensive, and antioxidant activities and identification of $\alpha$-glucosidase inhibitory peptides from soy protein," Food Science \& Nutrition, vol. 7, no. 5, pp. 1848-1856, 2019.

[64] N. Ktari, R. Ben Slama-Ben Salem, I. Bkhairia et al., "Functional properties and biological activities of peptides from zebra blenny protein hydrolysates fractionated using ultrafiltration," Food Bioscience, vol. 34, article 100539, 2020.

[65] K. Aoki, H. Sato, and Y. Terauchi, "Usefulness of antidiabetic alpha-glucosidase inhibitors: a review on the timing of administration and effects on gut hormones," Endocrine Journal, vol. 66, no. 5, pp. 395-401, 2019.

[66] Z. Yu, Y. Yin, W. Zhao, J. Liu, and F. Chen, "Anti-diabetic activity peptides from albumin against $\alpha$-glucosidase and $\alpha$ amylase," Food Chemistry, vol. 135, no. 3, pp. 2078-2085, 2012.

[67] A. Zambrowicz, E. Eckert, M. Pokora et al., "Antioxidant and antidiabetic activities of peptides isolated from a hydrolysate 
of an egg-yolk protein by-product prepared with a proteinase from Asian pumpkin (Cucurbita ficifolia)," RSC Advances, vol. 5, no. 14, pp. 10460-10467, 2015.

[68] S. Hu, X. Fan, P. Qi, and X. Zhang, "Identification of antidiabetes peptides from Spirulina platensis," Journal of Functional Foods, vol. 56, pp. 333-341, 2019.

[69] P. A. Harnedy-Rothwell, C. M. McLaughlin, M. B. O'Keeffe et al., "Identification and characterisation of peptides from a boarfish (Capros aper) protein hydrolysate displaying in vitro dipeptidyl peptidase-IV (DPP-IV) inhibitory and insulinotropic activity," Food Research International, vol. 131, article 108989, 2020.

[70] A. B. Nongonierma and R. J. FitzGerald, "Inhibition of dipeptidyl peptidase IV (DPP-IV) by proline containing caseinderived peptides," Journal of Functional Foods, vol. 5, no. 4, pp. 1909-1917, 2013.

[71] P. A. Harnedy, V. Parthsarathy, C. M. McLaughlin et al., "Blue whiting (Micromesistius poutassou) muscle protein hydrolysate with in vitro and in vivo antidiabetic properties," Journal of Functional Foods, vol. 40, pp. 137-145, 2018.

[72] V. Parthsarathy, C. M. McLaughlin, P. A. Harnedy et al., "Boarfish (Capros aper) protein hydrolysate has potent insulinotropic and GLP-1 secretory activityin vitroand acute glucose lowering effects in mice," International Journal of Food Science and Technology, vol. 54, no. 1, pp. 271-281, 2019.

[73] T. Wang, L. Zheng, T. Zhao et al., "Anti-diabetic effects of sea cucumber (Holothuria nobilis) hydrolysates in streptozotocin and high-fat-diet induced diabetic rats via activating the PI3K/Akt pathway," Journal of Functional Foods, vol. 75, article 104224, 2020.

[74] Q. Yuan, B. Zhan, M. Du, R. Chang, T. Li, and X. Mao, "Dietary milk fat globule membrane regulates JNK and PI3K/Akt pathway and ameliorates type 2 diabetes in mice induced by a high-fat diet and streptozotocin," Journal of Functional Foods, vol. 60, article 103435, 2019.

[75] J. Wang, T. Wu, L. Fang et al., "Anti-diabetic effect by walnut (Juglans mandshurica Maxim.)-derived peptide LPLLR through inhibiting $\alpha$-glucosidase and $\alpha$-amylase, and alleviating insulin resistance of hepatic HepG2 cells," Journal of Functional Foods, vol. 69, article 103944, 2020.

[76] T. Sartorius, A. Weidner, T. Dharsono, A. Boulier, M. Wilhelm, and C. Schön, "Postprandial Effects of a Proprietary Milk Protein Hydrolysate Containing Bioactive Peptides in Prediabetic Subjects," Nutrients, vol. 11, no. 7, p. 1700, 2019.

[77] H. F. Dale, C. Jensen, T. Hausken et al., "Effect of a cod protein hydrolysate on postprandial glucose metabolism in healthy subjects: a double-blind cross-over trial," Journal of Nutritional Science, vol. 7, article e33, 2018.

[78] S.-C. Ko, W.-K. Jung, S.-H. Lee, D. H. Lee, and Y.-J. Jeon, "Antihypertensive effect of an enzymatic hydrolysate fromStyela clavaflesh tissue in type 2 diabetic patients with hypertension," Nutrition Research and Practice, vol. 11, no. 5, pp. 396-401, 2017.

[79] K. Musa-Veloso, L. Paulionis, T. Pelipyagina, and M. Evans, "A randomized, double-blind, placebo-controlled, multicentre trial of the effects of a shrimp protein hydrolysate on blood pressure," International Journal of Hypertension, vol. 2019, Article ID 2345042, 13 pages, 2019.

[80] N. Wu, W. Xu, K. Liu, Y. Xia, and Shuangquan, “Angiotensin-converting enzyme inhibitory peptides from Lactobacil- lus delbrueckii QS306 fermented milk," Journal of Dairy Science, vol. 102, no. 7, pp. 5913-5921, 2019.

[81] T. Nakamura, J. Mizutani, K. Ohki et al., "Casein hydrolysate containing Val-Pro-Pro and Ile-Pro-Pro improves central blood pressure and arterial stiffness in hypertensive subjects: a randomized, double-blind, placebo-controlled trial," Atherosclerosis, vol. 219, no. 1, pp. 298-303, 2011.

[82] L. Xue, X. Wang, Z. Hu et al., "Identification and characterization of an angiotensin-converting enzyme inhibitory peptide derived from bovine casein," Peptides, vol. 99, pp. 161$168,2018$.

[83] P. Zhang, C. Chang, H. Liu, B. Li, Q. Yan, and Z. Jiang, "Identification of novel angiotensin I-converting enzyme (ACE) inhibitory peptides from wheat gluten hydrolysate by the protease of Pseudomonas aeruginosa," Journal of Functional Foods, vol. 65, article 103751, 2020.

[84] E. B.-M. Daliri, B. H. Lee, M. H. Park, J.-H. Kim, and D.H. Oh, "Novel angiotensin I-converting enzyme inhibitory peptides from soybean protein isolates fermented by Pediococcus pentosaceus SDL1409," LWT, vol. 93, pp. 88-93, 2018.

[85] S. Mäkinen, T. Streng, L. B. Larsen, A. Laine, and A. Pihlanto, "Angiotensin I-converting enzyme inhibitory and antihypertensive properties of potato and rapeseed protein-derived peptides," Journal of Functional Foods, vol. 25, pp. 160-173, 2016.

[86] C. C. Y. Sutopo, A. Sutrisno, L.-F. Wang, and J.-L. Hsu, "Identification of a potent angiotensin-I converting enzyme inhibitory peptide from black cumin seed hydrolysate using orthogonal bioassay-guided fractionations coupled with in silico screening," Process Biochemistry, vol. 95, pp. 204-213, 2020.

[87] P. Chen, L. Li, X. Huo et al., "New angiotensin-converting enzyme inhibitory peptide from Coix prolamin and its influence on the gene expression of renin-angiotensin system in vein endothelial cells," Journal of Cereal Science, vol. 96, article 103099, 2020.

[88] P. Li, J. Jia, M. Fang et al., "In vitro and in vivo ACE inhibitory of pistachio hydrolysates and in silico mechanism of identified peptide binding with ACE," Process Biochemistry, vol. 49, no. 5, pp. 898-904, 2014.

[89] C. Liu, L. Fang, W. Min, J. Liu, and H. Li, "Exploration of the molecular interactions between angiotensin-I-converting enzyme (ACE) and the inhibitory peptides derived from hazelnut (Corylus heterophylla Fisch.)," Food Chemistry, vol. 245, pp. 471-480, 2018.

[90] C. Sonklin, M. A. Alashi, N. Laohakunjit, O. Kerdchoechuen, and R. E. Aluko, "Identification of antihypertensive peptides from mung bean protein hydrolysate and their effects in spontaneously hypertensive rats," Journal of Functional Foods, vol. 64, article 103635, 2020.

[91] P. García-Mora, M. Martín-Martínez, M. Angeles Bonache et al., "Identification, functional gastrointestinal stability and molecular docking studies of lentil peptides with dual antioxidant and angiotensin I converting enzyme inhibitory activities," Food Chemistry, vol. 221, pp. 464-472, 2017.

[92] J.-G. Je, H. S. Kim, H. G. Lee et al., "Low-molecular weight peptides isolated from seahorse (Hippocampus abdominalis) improve vasodilation via inhibition of angiotensinconverting enzyme in vivo and in vitro," Process Biochemistry, vol. 95, pp. 30-35, 2020.

[93] S. Khueychai, N. Jangpromma, K. Choowongkomon et al., "A novel ACE inhibitory peptide derived from alkaline 
hydrolysis of ostrich (Struthio camelus) egg white ovalbumin," Process Biochemistry, vol. 73, pp. 235-245, 2018.

[94] J. K. Lee, J. K. Jeon, and H. G. Byun, “Antihypertensive effect of novel angiotensin I converting enzyme inhibitory peptide from chum salmon (Oncorhynchus keta) skin in spontaneously hypertensive rats," Journal of Functional Foods, vol. 7, pp. 381-389, 2014.

[95] D.-H. Ngo, K. H. Kang, B. M. Ryu et al., “Angiotensin-I converting enzyme inhibitory peptides from antihypertensive skate (Okamejei kenojei) skin gelatin hydrolysate in spontaneously hypertensive rats," Food Chemistry, vol. 174, pp. 37-43, 2015.

[96] R. Balti, A. Bougatef, A. Sila, D. Guillochon, P. Dhulster, and N. Nedjar-Arroume, "Nine novel angiotensin I-converting enzyme (ACE) inhibitory peptides from cuttlefish (Sepia officinalis) muscle protein hydrolysates and antihypertensive effect of the potent active peptide in spontaneously hypertensive rats," Food Chemistry, vol. 170, pp. 519-525, 2015.

[97] M. Guo, X. Chen, Y. Wu et al., “Angiotensin I-converting enzyme inhibitory peptides from Sipuncula (Phascolosoma esculenta): Purification, identification, molecular docking and antihypertensive effects on spontaneously hypertensive rats," Process Biochemistry, vol. 63, pp. 84-95, 2017.

[98] C. Zhang, Y. Zhang, Z. Wang, S. Chen, and Y. Luo, "Production and identification of antioxidant and angiotensinconverting enzyme inhibition and dipeptidyl peptidase IV inhibitory peptides from bighead carp (Hypophthalmichthys nobilis) muscle hydrolysate," Journal of Functional Foods, vol. 35, pp. 224-235, 2017.

[99] S. Y. Lee and S. J. Hur, "Purification of novel angiotensin converting enzyme inhibitory peptides from beef myofibrillar proteins and analysis of their effect in spontaneously hypertensive rat model," Biomedicine \& Pharmacotherapy, vol. 116, p. 109046, 2019.

[100] I. Jemil, L. Mora, R. Nasri et al., "A peptidomic approach for the identification of antioxidant and ACE-inhibitory peptides in sardinelle protein hydrolysates fermented by Bacillus subtilis A26 and Bacillus amyloliquefaciens An6," Food Research International, vol. 89, Part 1, pp. 347-358, 2016.

[101] D. Furman, J. Campisi, E. Verdin et al., "Chronic inflammation in the etiology of disease across the life span," Nature Medicine, vol. 25, no. 12, pp. 1822-1832, 2019.

[102] M. Oyama, T. van Hung, K. Yoda, F. He, and T. Suzuki, “A novel whey tetrapeptide IPAV reduces interleukin- 8 production induced by TNF- $\alpha$ in human intestinal Caco- 2 cells," Journal of Functional Foods, vol. 35, pp. 376-383, 2017.

[103] X. Wang, Y. Zhao, Y. Yao et al., “Anti-inflammatory activity of di-peptides derived from ovotransferrin by simulated peptide-cut in TNF- $\alpha$-induced Caco- 2 cells," Journal of Functional Foods, vol. 37, pp. 424-432, 2017.

[104] S. Chakrabarti, F. Jahandideh, and J. Wu, "Food-derived bioactive peptides on inflammation and oxidative stress," BioMed Research International, vol. 2014, Article ID 608979, 11 pages, 2014.

[105] S. Li, L. Liu, G. He, and J. Wu, "Molecular targets and mechanisms of bioactive peptides against metabolic syndromes," Food \& Function, vol. 9, no. 1, pp. 42-52, 2018.

[106] C. Dai, L. Dai, F. J. Yu et al., "Chemical and biological characteristics of hydrolysate of crucian carp swim bladder: focus on preventing ulcerative colitis," Journal of Functional Foods, vol. 75, article 104256, 2020.
[107] A. Mukhopadhya, N. Noronha, B. Bahar et al., “Anti-inflammatory effects of a casein hydrolysate and its peptideenriched fractions on TNF $\alpha$-challenged Caco- 2 cells and LPS-challenged porcine colonic explants," Food Science \& Nutrition, vol. 2, no. 6, pp. 712-723, 2014.

[108] J. Kovacs-Nolan, H. Zhang, M. Ibuki et al., "The PepT1transportable soy tripeptide VPY reduces intestinal inflammation," Biochimica et Biophysica Acta (BBA) - General Subjects, vol. 1820, no. 11, pp. 1753-1763, 2012.

[109] Q. Liang, X. Ren, M. Chalamaiah, and H. Ma, "Simulated gastrointestinal digests of corn protein hydrolysate alleviate inflammation in caco-2 cells and a mouse model of colitis," Journal of Food Science and Technology, vol. 57, no. 6, pp. 2079-2088, 2020.

[110] M. Zhang, Y. Zhao, Y. Yao et al., "Isolation and identification of peptides from simulated gastrointestinal digestion of preserved egg white and their anti-inflammatory activity in TNF- $\alpha$-induced Caco-2 cells," The Journal of Nutritional Biochemistry, vol. 63, pp. 44-53, 2019.

[111] M. Zhang, Y. Zhao, N. Wu et al., "The anti-inflammatory activity of peptides from simulated gastrointestinal digestion of preserved egg white in DSS-induced mouse colitis," Food \& Function, vol. 9, no. 12, pp. 6444-6454, 2018.

[112] T. Liu, L. Zhang, D. Joo, and S. C. Sun, "NF- $\kappa$ B signaling in inflammation," Signal Transduction and Targeted Therapy, vol. 2, no. 1, article 17023, 2017.

[113] Y. Chen, H. Zhang, L. Mats et al., "Anti-inflammatory effect and cellular uptake mechanism of peptides from common bean (Phaseolus vulga L.) milk and yogurts in Caco-2 monoand Caco-2/EA.hy926 co-culture models," Journal of Agricultural and Food Chemistry, vol. 67, no. 30, pp. 8370-8381, 2019.

[114] M. Memarpoor-Yazdi, H. Mahaki, and H. Zare-Zardini, "Antioxidant activity of protein hydrolysates and purified peptides from Zizyphus jujuba fruits," Journal of Functional Foods, vol. 5, no. 1, pp. 62-70, 2013.

[115] L. Wang, L. Ding, Z. Yu, T. Zhang, S. Ma, and J. Liu, "Intracellular ROS scavenging and antioxidant enzyme regulating capacities of corn gluten meal-derived antioxidant peptides in HepG2 cells," Food Research International, vol. 90, pp. 33-41, 2016.

[116] P. A. Harnedy, M. B. O'Keeffe, and R. J. FitzGerald, "Fractionation and identification of antioxidant peptides from an enzymatically hydrolysed Palmaria palmata protein isolate," Food Research International, vol. 100, Part 1, pp. 416-422, 2017.

[117] Z. Karami, S. H. Peighambardoust, J. Hesari, B. Akbari-Adergani, and D. Andreu, "Antioxidant, anticancer and ACEinhibitory activities of bioactive peptides from wheat germ protein hydrolysates," Food Bioscience, vol. 32, article 100450, 2019.

[118] J. Tkaczewska, B. Borczak, E. Piątkowska, J. Kapusta-Duch, M. Morawska, and T. Czech, "Effect of protein hydrolysates from carp (Cyprinus carpio) skin gelatine on oxidative stress biomarkers and other blood parameters in healthy rats," Journal of Functional Foods, vol. 60, article 103411, 2019.

[119] M. Kumar, T. Ahmad, A. Sharma et al., "Let-7 microRNAmediated regulation of IL-13 and allergic airway inflammation," The Journal of Allergy and Clinical Immunology, vol. 128, no. 5, pp. 1077-1085.e10, 2011.

[120] K. M. I. Bashir, J. H. Sohn, J. S. Kim, and J. S. Choi, "Identification and characterization of novel antioxidant peptides 
from mackerel (Scomber japonicus) muscle protein hydrolysates," Food Chemistry, vol. 323, article 126809, 2020.

[121] Z. Ji, J. Mao, S. Chen, and J. Mao, "Antioxidant and antiinflammatory activity of peptides from foxtail millet (Setaria italica) prolamins in HaCaT cells and RAW264.7 murine macrophages," Food Bioscience, vol. 36, article 100636, 2020.

[122] Z. Wang, X. Liu, H. Xie et al., "Antioxidant activity and functional properties of Alcalase-hydrolyzed scallop protein hydrolysate and its role in the inhibition of cytotoxicity in vitro," Food Chemistry, vol. 344, p. 128566, 2021.

[123] M.-J. Tsou, F. J. Kao, C. K. Tseng, and W. D. Chiang, "Enhancing the anti-adipogenic activity of soy protein by limited hydrolysis with flavourzyme and ultrafiltration," Food Chemistry, vol. 122, no. 1, pp. 243-248, 2010.

[124] M.-R. Kim, J. W. Kim, J. B. Park, Y. K. Hong, S. K. Ku, and J. S. Choi, "Anti-obesity effects of yellow catfish protein hydrolysate on mice fed a $45 \% \mathrm{kcal}$ high-fat diet," International Journal of Molecular Medicine, vol. 40, no. 3, pp. 784-800, 2017.

[125] S. Jafar, H. Kamal, P. Mudgil, H. M. Hassan, and S. Maqsood, "Camel whey protein hydrolysates displayed enhanced cholesteryl esterase and lipase inhibitory, anti-hypertensive and anti-haemolytic properties," $L W T$, vol. 98, pp. 212-218, 2018.

[126] M. Woo, Y. Song, K. H. Kang, and J. Noh, “Anti-obesity effects of collagen peptide derived from skate (Raja kenojei) skin through regulation of lipid metabolism," Marine Drugs, vol. 16, no. 9, p. 306, 2018.

[127] Y.-T. Tung, H. L. Chen, H. S. Wu, M. H. Ho, K. Y. Chong, and C. M. Chen, "Kefir peptides prevent hyperlipidemia and obesity in high-fat-diet-induced obese rats via lipid metabolism modulation," Molecular Nutrition \& Food Research, vol. 62, no. 3, article 1700505, 2018.

[128] Z. Shi, Y. Hao, C. Teng, Y. Yao, and G. Ren, "Functional properties and adipogenesis inhibitory activity of protein hydrolysates from quinoa (Chenopodium quinoa Willd.)," Food Science \& Nutrition, vol. 7, no. 6, pp. 2103-2112, 2019.

[129] D. Fangmann, C. Geisler, K. Schlicht et al., "Differential effects of protein intake versus intake of a defined oligopeptide on FGF-21 in obese human subjects in vivo," Clinical Nutrition, vol. 40, no. 2, pp. 600-607, 2020.

[130] T. Hatanaka, Y. Inoue, J. Arima et al., "Production of dipeptidyl peptidase IV inhibitory peptides from defatted rice bran," Food Chemistry, vol. 134, no. 2, pp. 797-802, 2012.

[131] T. Lafarga, P. O’Connor, and M. Hayes, "Identification of novel dipeptidyl peptidase-IV and angiotensin-I-converting enzyme inhibitory peptides from meat proteins using in silico analysis," Peptides, vol. 59, pp. 53-62, 2014.

[132] S.-L. Huang, C.-C. Hung, C.-L. Jao, Y.-S. Tung, and K.C. Hsu, "Porcine skin gelatin hydrolysate as a dipeptidyl peptidase IV inhibitor improves glycemic control in streptozotocin-induced diabetic rats," Journal of Functional Foods, vol. 11, pp. 235-242, 2014.

[133] L. Mojica, E. Gonzalez de Mejia, M. Á. Granados-Silvestre, and M. Menjivar, "Evaluation of the hypoglycemic potential of a black bean hydrolyzed protein isolate and its pure peptides using in silico, in vitro and in vivo approaches," Journal of Functional Foods, vol. 31, pp. 274-286, 2017.

[134] M. Kato, T. Nakanishi, T. Tani, and T. Tsuda, "Low-molecular fraction of wheat protein hydrolysate stimulates glucagonlike peptide- 1 secretion in an enteroendocrine $\mathrm{L}$ cell line and improves glucose tolerance in rats," Nutrition Research, vol. 37, pp. 37-45, 2017.

[135] F. Wang, Y. Zhang, T. Yu et al., "Oat globulin peptides regulate antidiabetic drug targets and glucose transporters in Caco-2 cells," Journal of Functional Foods, vol. 42, pp. 1220, 2018.

[136] E. Valencia-Mejía, K. A. Batista, J. J. A. Fernández, and K. F. Fernandes, "Antihyperglycemic and hypoglycemic activity of naturally occurring peptides and protein hydrolysates from easy-to-cook and hard-to-cook beans (Phaseolus vulgaris L.)," Food Research International, vol. 121, pp. 238-246, 2019.

[137] K. Wang, X. Yang, W. Lou, and X. Zhang, "Discovery of dipeptidyl peptidase 4 inhibitory peptides from Largemouth bass (Micropterus salmoides) by a comprehensive approach," Bioorganic Chemistry, vol. 105, article 104432, 2020.

[138] C. Jia, N. Hussain, O. Joy Ujiroghene et al., "Generation and characterization of dipeptidyl peptidase-IV inhibitory peptides from trypsin-hydrolyzed $\alpha$-lactalbumin-rich whey proteins," Food Chemistry, vol. 318, article 126333, 2020.

[139] C. M. McLaughlin, S. J. Sharkey, P. Harnedy-Rothwell et al., "Twice daily oral administration of Palmaria palmata protein hydrolysate reduces food intake in streptozotocin induced diabetic mice, improving glycaemic control and lipid profiles," Journal of Functional Foods, vol. 73, article 104101, 2020.

[140] H. Li, N. Prairie, C. C. Udenigwe et al., "Blood pressure lowering effect of a pea protein hydrolysate in hypertensive rats and humans," Journal of Agricultural and Food Chemistry, vol. 59, no. 18, pp. 9854-9860, 2011.

[141] D. Young, M. Ibuki, T. Nakamori, M. Fan, and Y. Mine, "Soyderived Di- and tripeptides alleviate colon and ileum inflammation in pigs with dextran sodium sulfate-induced colitis," The Journal of Nutrition, vol. 142, no. 2, pp. 363-368, 2012.

[142] T. Grimstad, B. Bjørndal, D. Cacabelos et al., "A salmon peptide diet alleviates experimental colitis as compared with fish oil," Journal of Nutritional Science, vol. 2, p. e2, 2013.

[143] Y. Shi, P. Rupa, B. Jiang, and Y. Mine, "Hydrolysate from eggshell membrane ameliorates intestinal inflammation in mice," International Journal of Molecular Sciences, vol. 15, no. 12, pp. 22728-22742, 2014.

[144] S. K. Ramadass, S. L. Jabaris, R. K. Perumal, V. I. HairulIslam, A. Gopinath, and B. Madhan, "Type I collagen and its daughter peptides for targeting mucosal healing in ulcerative colitis: a new treatment strategy," European Journal of Pharmaceutical Sciences, vol. 91, pp. 216-224, 2016.

[145] Y. Zhao, Y. Yao, M. Xu, S. Wang, X. Wang, and Y. Tu, "Simulated gastrointestinal digest from preserved egg white exerts anti- inflammatory effects on Caco- 2 cells and a mouse model of DSS-induced colitis," Journal of Functional Foods, vol. 35, pp. 655-665, 2017. 